In cooperation with North Dakota State University Agriculture Research Extension

\title{
Water-Quality Characteristics in Runoff for Three Discovery Farms in North Dakota, 2008-12
}
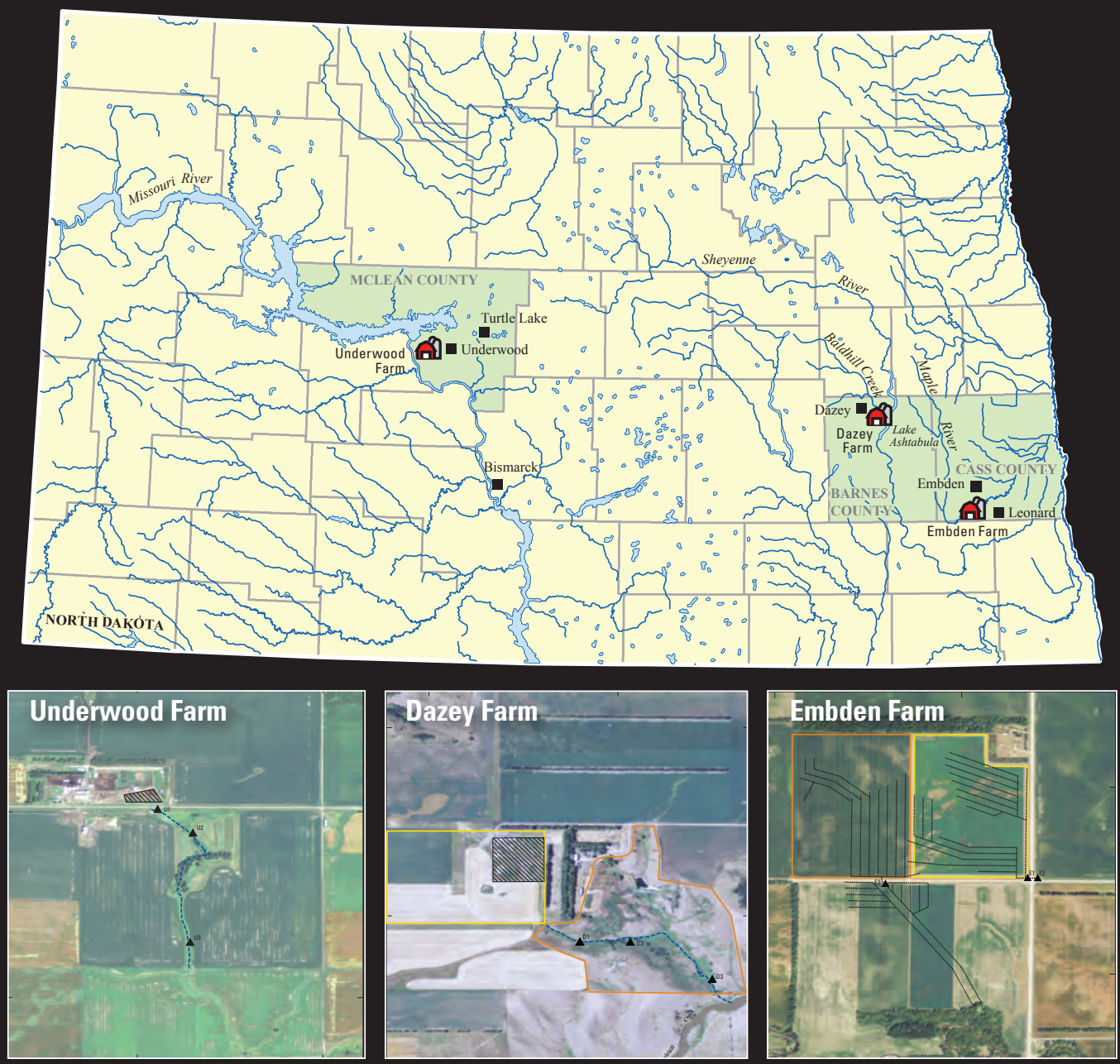

Scientific Investigations Report 2014-5212 



\section{Water-Quality Characteristics in Runoff for Three Discovery Farms in North Dakota, 2008-12}

By Rochelle A. Nustad, Kathleen M. Rowland, and Ronald G.Wiederholt

In cooperation with North Dakota State University Agriculture Research Extension

Scientific Investigations Report 2014-5212 


\title{
U.S. Department of the Interior SALLY JEWELL, Secretary
}

\section{U.S. Geological Survey \\ Suzette M. Kimball, Acting Director}

\author{
U.S. Geological Survey, Reston, Virginia: 2015
}

For more information on the USGS - the Federal source for science about the Earth, its natural and living resources, natural hazards, and the environment—visit http://www.usgs.gov or call 1-888-ASK-USGS.

For an overview of USGS information products, including maps, imagery, and publications, visit http://www.usgs.gov/pubprod/.

Any use of trade, firm, or product names is for descriptive purposes only and does not imply endorsement by the U.S. Government.

Although this information product, for the most part, is in the public domain, it also may contain copyrighted materials as noted in the text. Permission to reproduce copyrighted items must be secured from the copyright owner.

Suggested citation:

Nustad, R.A., Rowland, K.M., and Wiederholt, R.G., 2015, Water-quality characteristics in runoff for three discovery farms in North Dakota, 2008-12: U.S. Geological Survey Scientific Investigations Report 2014-5212, 31 p., http:// dx.doi.org/10.3133/sir20145212.

ISSN 2328-0328 (online) 


\section{Contents}

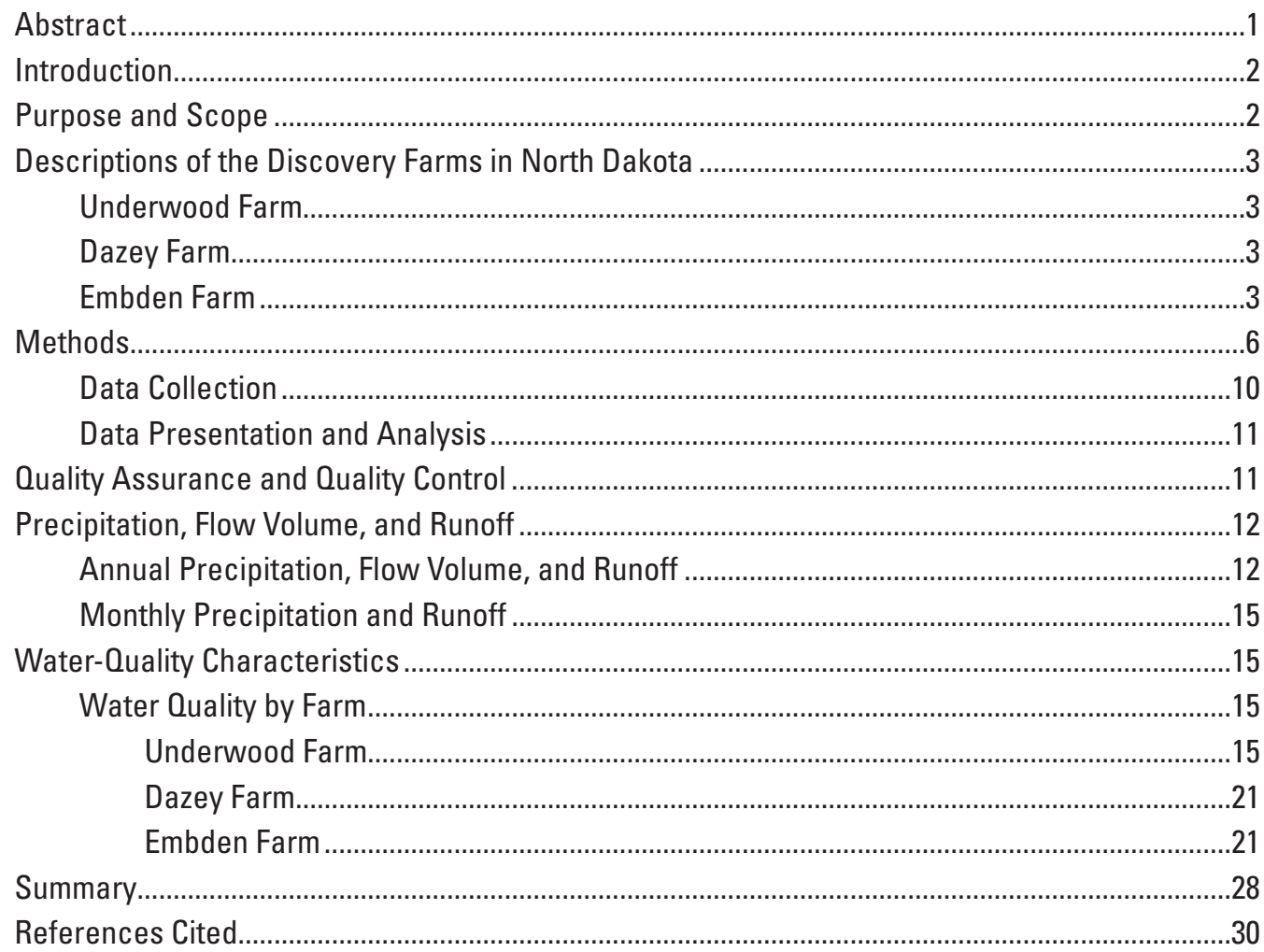

\section{Figures}

1. Map showing location of Discovery Farms in North Dakota ............................................4

2. Photographs showing equipment installed at Discovery Farms sites in North Dakota ...6

3. Map showing location of monitoring sites and aerial view of Underwood Farm in North Dakota ..............................................................................................................

4. Map showing location of monitoring sites and aerial view of Dazey Farm in North

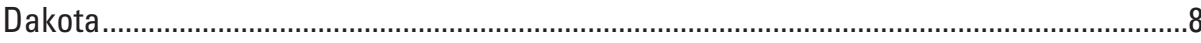

5. Map showing location of monitoring sites and aerial view of Embden Farm in

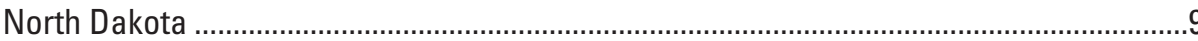

6. Graphs showing annual precipitation for Discovery Farms in North Dakota from March through October and 30-year mean annual precipitation; the 30-year mean annual is an average of National Weather Service sites located near the Underwood, Dazey, and Embden Farms from March through October

7. Graphs showing flow volume for Discovery Farms in North Dakota from March through October, 2009-2012.

8. Graphs showing annual runoff and runoff as a percentage of annual precipitation for Discovery Farms in North Dakota from March through October 2009-2012.

9. Graphs showing monthly precipitation and monthly mean precipitation for Discovery Farms in North Dakota, 2009-2012 
10. Graphs showing monthly runoff and monthly mean runoff for surface drainage sites at Discovery Farms in North Dakota, 2009-2012.

11. Boxplots showing distribution of constituent concentrations at Underwood Discovery Farms, North Dakota, 2008-2012

12. Pie charts showing speciation of nitrogen at Underwood and Dazey Farms, North Dakota, 2008-2012

13. Graphs showing annual loads for Discovery Farms in North Dakota, 2009-2012 ..........22

14. Graphs showing annual yields for Discovery Farms in North Dakota, 2009-2012..........23

15. Boxplots showing distribution of constituent concentrations at Dazey Farm, North Dakota, 2009-2012

16. Boxplots showing distribution of constituent concentrations at Embden Farm, North Dakota, 2009-2012

17. Pie charts showing speciation of nitrogen at Embden Farm, North Dakota, 2009-2012

\section{Tables}

1. Location, elevation, drainage area, mean basin slope, flume style, date of construction, and period of record for monitoring sites for Discovery Farms, North Dakota

2. Results of quality-assurance samples for chloride, nutrient and suspended-sediment concentrations for samples collected for Discovery Farms, 2008-12

3. Estimate of runoff for subsurface drainage tile sites, E2 and E3, using surface drainage area at Embden Farm, 2010-12.

4. Number of samples collected each year for Discovery Farms sites, June 2008-0ctober 2012. 


\section{Conversion Factors}

IInternational System of Units

\begin{tabular}{|c|c|c|}
\hline Multiply & By & To obtain \\
\hline \multicolumn{3}{|c|}{ Length } \\
\hline inch (in.) & 2.54 & centimeter $(\mathrm{cm})$ \\
\hline inch (in.) & 25.4 & millimeter $(\mathrm{mm})$ \\
\hline foot $(\mathrm{ft})$ & 0.3048 & meter $(\mathrm{m})$ \\
\hline mile (mi) & 1.609 & kilometer $(\mathrm{km})$ \\
\hline \multicolumn{3}{|c|}{ Area } \\
\hline acre & 4,047 & square meter $\left(\mathrm{m}^{2}\right)$ \\
\hline acre & 0.4047 & hectare (ha) \\
\hline acre & 0.4047 & square hectometer $\left(\mathrm{hm}^{2}\right)$ \\
\hline acre & 0.004047 & square kilometer $\left(\mathrm{km}^{2}\right)$ \\
\hline \multicolumn{3}{|c|}{ Volume } \\
\hline cubic foot $\left(\mathrm{ft}^{3}\right)$ & 28.32 & cubic decimeter $\left(\mathrm{dm}^{3}\right)$ \\
\hline cubic foot $\left(\mathrm{ft}^{3}\right)$ & 0.02832 & cubic meter $\left(\mathrm{m}^{3}\right)$ \\
\hline million gallons (Mgal) & 3,785 & cubic meter $\left(\mathrm{m}^{3}\right)$ \\
\hline \multicolumn{3}{|c|}{ Flow rate } \\
\hline cubic foot per second $\left(\mathrm{ft}^{3} / \mathrm{s}\right)$ & 0.02832 & cubic meter per second $\left(\mathrm{m}^{3} / \mathrm{s}\right)$ \\
\hline \multicolumn{3}{|c|}{ Mass } \\
\hline pound per day (lb/d) & 0.4536 & kilogram (kg) \\
\hline
\end{tabular}

Temperature in degrees Fahrenheit $\left({ }^{\circ} \mathrm{F}\right)$ may be converted to degrees Celsius $\left({ }^{\circ} \mathrm{C}\right)$ as follows: ${ }^{\circ} \mathrm{C}=\left({ }^{\circ} \mathrm{F}-32\right) / 1.8$

\section{Supplemental Information}

Concentrations of chemical constituents in water are given in milligrams per liter (mg/L). 



\title{
Water-Quality Characteristics in Runoff for Three Discovery Farms in North Dakota, 2008-12
}

\author{
By Rochelle A. Nustad, Kathleen M. Rowland, and Ronald G. Wiederholt
}

\section{Abstract}

North Dakota has implemented several policies with the goal of minimizing runoff from animal feeding operations; however, little data have been collected to evaluate the effects of runoff from feeding operations on water quality or improvements in water quality resulting from changes in animal feeding operation practices. In response to this lack of data, the U.S. Geological Survey in cooperation with North Dakota State University Agriculture Research Extension and in collaboration with North Dakota State Department of Health, North Dakota State Water Commission, U.S. Environmental Protection Agency, and several agricultural producers helped organize a Discovery Farms program in North Dakota in 2007. Discharge measurements and water-quality samples collected at the three Farms (Underwood, Dazey, and Embden) were used to describe water-quality characteristics in runoff, and compute estimates of annual loads and yields for selected constituents from spring 2008 through fall 2012.

At Underwood Farm, concentrations generally decreased from upstream to downstream because of proximity to the feedlot and grassy depressions located between sites. With the exception of nitrate plus nitrite, a statistically significant decrease in concentration from upstream to downstream generally was observed. For nitrate plus nitrite, the surface runoff processes that dominated other constituents (dilution, settling out, vegetative uptake) were moderated by other processes specific to nitrate plus nitrite (high solubility, nitrification, and denitrification), resulting in no significant change in concentrations from upstream to downstream. For constituents other than nitrate plus nitrite, dilution, settling out of sediment particles, and vegetative uptake likely contributed to the decrease in constituent concentration from upstream to downstream. The predominant form of nitrogen at Underwood Farm was organic nitrogen (59 percent of total nitrogen), which is consistent with surface drainage sites at Discovery Farms in Wisconsin. For chloride, suspended sediment, total phosphorus, and ammonia, the largest loads typically were at the upstream site, and the smallest loads were observed at the downstream site. Consistent with annual flow volumes, for constituents other than nitrate plus nitrite, the smallest annual loads were in 2012, and the largest annual loads were in 2011.
Although the largest nitrate plus nitrite loads generally were observed in 2010, 2011 was the year with the largest amount of flow volume. The temporal distribution of precipitation may have contributed to the larger nitrate plus nitrite loads in 2010. With the exception of nitrate plus nitrite, the largest annual yields at Underwood Farm were in 2011 at the most upstream site, and the smallest annual yields were in 2012 at the most downstream site. The larger yield in 2011 relates well with annual runoff in 2011 at Underwood Farm, which, on average, was 1.5 times greater than runoff in 2010 .

Variability in concentrations among sites at Dazey Farm was predominantly affected by local topography and surfacegroundwater interactions. Chloride concentrations were highest at the site farthest downstream likely because of groundwater contribution. Suspended sediment, total phosphorus, and ammonia concentrations were significantly lower at the downstream site likely because of dilution and settling out of sediment. Nitrate plus nitrite concentrations were not significantly different from upstream to downstream likely because of surface-groundwater interaction, nitrification, and denitrification. Similar to Underwood Farm, the predominant form of nitrogen at Dazey Farm was organic nitrogen. For suspended sediment, total phosphorus, and ammonia, annual loads and yields at Dazey Farm were larger in 2010 than 2011, which was consistent with the pattern in precipitation and runoff. For chloride and nitrate plus nitrite, the largest annual loads did not coincide with the year of largest runoff, which may be caused by groundwater interaction with the surface runoff.

At Embden Farm, constituent concentrations were significantly different between surface drainage and subsurface drainage systems for all constituents except ammonia. Total phosphorus concentrations were significantly higher at the surface drainage site. Nitrate plus nitrite concentrations and total nitrogen concentrations were 10 to 100 times higher at subsurface drainage sites compared to the surface drainage site. Similar to nitrate plus nitrite, chloride concentrations were significantly higher at subsurface drainage sites than the surface drainage site. High solubility allows nitrate plus nitrite to readily flow through the soil and into tile lines, but groundwater also may be contributing to higher nitrate plus nitrite and chloride concentrations at the subsurface drainage sites. The speciation of nitrogen between the surface drainage site and subsurface drainage sites was distinctly different. 
The predominant form of nitrogen at the surface drainage site was organic nitrogen (68 percent), which is consistent with surface drainage sites at Underwood and Dazey Farms. For the subsurface drainage sites, the predominant form of nitrogen was nitrate plus nitrite (93 percent), which is consistent with subsurface drainage sites at Discovery Farms in Wisconsin. At the Embden Farm, during the wet years of 2010 and 2011, the subsurface drainage sites had the highest flow volumes and the largest annual loads.

Consistent patterns in water quality emerged at each individual farm, but similarities among farms also were observed. Suspended sediment, total phosphorus, and ammonia concentrations generally decreased downstream from feeding areas, and were primarily affected by surface runoff processes such as dilution, settling out of sediment, or vegetative uptake. Because surface runoff affects these constituents, increased annual surface runoff tended to result in increased loads and yields. No significant change in nitrate plus nitrite concentration were observed downstream from feeding areas because additional processes such as high solubility, nitrification, denitrification, and surface-groundwater interaction affect nitrate plus nitrite. For nitrate plus nitrite, increases in annual runoff did not consistently relate to increases in annual loads and yields. It seems that temporal distribution of precipitation and surface-groundwater interaction affected nitrate plus nitrite loads and yields. For surface drainage sites, the primary form of nitrogen was organic nitrogen whereas for subsurface drainage sites, the primary form of nitrogen was nitrate plus nitrite nitrogen.

\section{Introduction}

In North Dakota, animal feeding operations, manure disposal, and fertilizer application to crops commonly increase nutrient-bearing materials on the landscape. During runoff conditions, nutrients and other constituents in the materials could enter waterways and potentially contaminate downstream water supplies. North Dakota has a well-established group of watershed projects that have successfully improved manure management across the State (North Dakota Department of Health, 2012). North Dakota also has implemented several policies with the goal of minimizing runoff from animal feeding operations (North Dakota Department of Health, 2014); however, little data have been collected to evaluate the effects of runoff from feeding operations on water quality or improvements in water quality resulting from changes in animal feeding operation practices. In response to this lack of data, the U.S. Geological Survey (USGS) in cooperation with North Dakota State University Agriculture Research Extension and in collaboration with North Dakota State Department of Health, North Dakota State Water Commission, U.S. Environmental Protection Agency, and several agricultural producers helped organize a Discovery Farms program in North Dakota in 2007. This program, modeled after the Wisconsin Discovery Farms program (Stuntebeck and others, 2008), was established to collect and analyze water-quality information from agricultural lands and livestock feeding areas. An additional goal of Discovery Farms is to document the effectiveness of producer-driven solutions at minimizing negative effects on water quality.

Constituents that are present in runoff from crop and cattle operations include nutrients such as phosphorus and nitrogen, chloride, and suspended sediment. Runoff, measured in depth, is defined as the amount of water coming off the landscape in response to precipitation. The amount of each constituent in runoff can be expressed by concentration (mass per unit volume), loads (mass per unit time), or yields (mass per unit area). Constituents are affected by a variety of factors including background level from natural sources, land use management, topography, and soil type. Excess amounts of these constituents affect receiving waters such as rivers and lakes. Farm practices that prevent loss of these constituents are beneficial to receiving waters and to farmers that implement those practices.

Discovery Farms in North Dakota are working farms and ranches in the State whose operators are collaborating with local, State, and Federal natural resources agencies to demonstrate and evaluate the effectiveness of different management practices in reducing negative environmental effects while maintaining profitability. Goals of Discovery Farms include the following: (1) encourage responsible development of a diverse livestock industry in the State that will benefit crop and livestock producers while protecting the natural resources; (2) ensure a coordinated approach to the development and management of regulatory practices; (3) document and quantify the positive and negative effects of farming and ranching practices; (4) provide unbiased, reliable information to the general public, agricultural producers, and policymakers; (5) enhance communication and information sharing among agricultural producers, researchers, educators, the general public, and regulatory agencies; and (6) provide a platform for agricultural systems research through cooperation with interested research institutions (North Dakota State University, 2009).

\section{Purpose and Scope}

This report describes the three Discovery Farms in North Dakota, and procedures used to obtain discharge and waterquality samples. The purpose of this report is to describe water-quality characteristics in runoff, and estimate annual loads and yields for selected constituents from spring 2008 through fall 2012 at the three Discovery Farms in North Dakota. In addition, precipitation, flow volume, and runoff are presented. 


\section{Descriptions of the Discovery Farms in North Dakota}

Discovery Farms were established in North Dakota in late 2007 near Underwood in McLean County (hereafter referred to as "Underwood Farm"), in early 2008 near Dazey in Barnes County (hereafter referred to as "Dazey Farm"), and in late 2008 near Embden in Cass County (hereafter referred to as "Embden Farm") (fig. 1). Three data-collection sites were located at each farm. Each site contained a refrigerated automated water sampler that holds 24 1,000-milliliter (mL) sample bottles, a datalogger, a bubble-gage system (Sauer and Turnipseed, 2010), and a flume (table 1, fig. 2). At Embden Farm, an extra-large 60-degree $V$ trapezoidal flume was installed in the ground at sites E2 and E3 to capture runoff from subsurface drainage tiles. A tipping-bucket rain gage was installed at one site on each farm (table 1). Additional location information for the farms is presented in table 1.

The climate of Discovery Farms in North Dakota is classified as continental with a similar range in average temperatures and precipitation among the farms. The average air temperature, based on the period from 1981 to 2010, ranges from 40 degrees Fahrenheit $\left({ }^{\circ} \mathrm{F}\right)$ near Dazey Farm to $43^{\circ} \mathrm{F}$ near Embden Farm (North Dakota Agricultural Weather Network, 2013). Summer (June-August) temperatures average between 63 and $69^{\circ} \mathrm{F}$, and winter (December-February) temperatures average between 8 and $17^{\circ} \mathrm{F}$ (North Dakota Agricultural Weather Network, 2013). Average annual precipitation for the same period ranges from 17.6 inches (in.) near Underwood Farm to 22.3 in. near Embden Farm (North Dakota Agricultural Weather Network, 2013). Most of the precipitation falls as rain in May through August near Dazey and Embden Farms, and May through July near Underwood Farm (North Dakota Agricultural Weather Network, 2013). Precipitation amounts are least during winter months averaging between 0.44 and 0.62 in. (North Dakota Agricultural Weather Network, 2013). During winter months, precipitation typically falls as snow. Average annual snowfall ranges from about 35 in. near Dazey Farm to 40 in. near Underwood Farm (North Dakota State Climate Office, 2013a). The average number of days of snow cover of 1 in. or more is about 100 days for all of the farms (Jensen, [n.d.]).

\section{Underwood Farm}

Underwood Farm is a crop and cattle operation located about 8 miles (mi) west of Underwood, North Dakota, and about 3 mi east of the Missouri River (fig. 1). Underwood Farm is located on level to rolling topography underlain by the moderately well-drained silty loam soils of the Coteau Slope physiographic region of North Dakota (Bluemle and Biek, 2007). A feedlot is located at the southeast quadrant of the farmstead, and cropland makes up most of the surrounding area (fig. 3). Beef cows are placed in the feedlot during the winter months and remain there through the early spring during calving. Once the cows have calved, they are moved to an offsite pasture (not shown) with their calves during the summer months and are kept together until weaning in early fall. Weaned calves also are placed in the feedlot in the fall and remain there until late winter before being moved to finishing lots in other parts of the state. Most of the pens in the feedlot are empty during the summer months. Manure accumulation from the winter months is scraped and piled in the pens after the cows and calves are sent to pasture. Manure is stored in the empty pens until late summer when it is spread on surrounding cropland to be used as a crop fertilizer. Runoff from the farmstead and feedlot enters a waterway that generally trends from north to south (fig. 3). Runoff from the farm contributes to a small drainage basin that flows into the Missouri River. Three data-collection sites are located along the waterway south of the farm (fig. 3). Shelters were brought in or built onsite to house the automated samplers and the dataloggers. The drainage area for each of the sites ranges from 87 to 1,976 acres (table 1).

\section{Dazey Farm}

Dazey Farm is a crop and cattle operation located about 6 mi east and 2 mi south of Dazey, N. Dak., and 3 mi west of Lake Ashtabula (fig. 1). Dazey Farm is located on sloping topography underlain by well-drained loams of the Glaciated Plains physiographic region of North Dakota (Bluemle and Biek, 2007). A feedlot and winter cattle feeding area is located to the west of the farmhouse, and cropland makes up most of the surrounding area (fig. 4). After being brought in from pasture in the fall, the beef cows are wintered on the cattle feeding area, which is primarily cropland. The cattle graze the crop residue and, if supplemented with stored feed, the feeding areas are randomly located in the cropland area to decrease the amount of concentrated feeding areas. Feeding area runoff from the cropland, which can flow rapidly, travels mostly eastward along a waterway into Baldhill Creek (fig. 4) and then into Lake Ashtabula (not shown). The waterway traverses through a pasture, which serves as a calving area for the beef cows in early spring. Three data-collection sites were established, and shelters were built at the sites along the waterway to house the automated samplers and the dataloggers. The most downstream site (D3) receives runoff from the cattle feeding area as well as runoff from cropland on neighboring farms. The drainage area for the three sites ranges from 30 to 341 acres (table 1).

\section{Embden Farm}

Embden Farm is a combination crop and cattle production operation located about $8 \mathrm{mi}$ south of Embden, N. Dak. and about 1 mi north of the Maple River (fig. 1). Embden Farm is located on nearly level ground underlain by sandy loam soils of the Red River Valley physiographic region of 


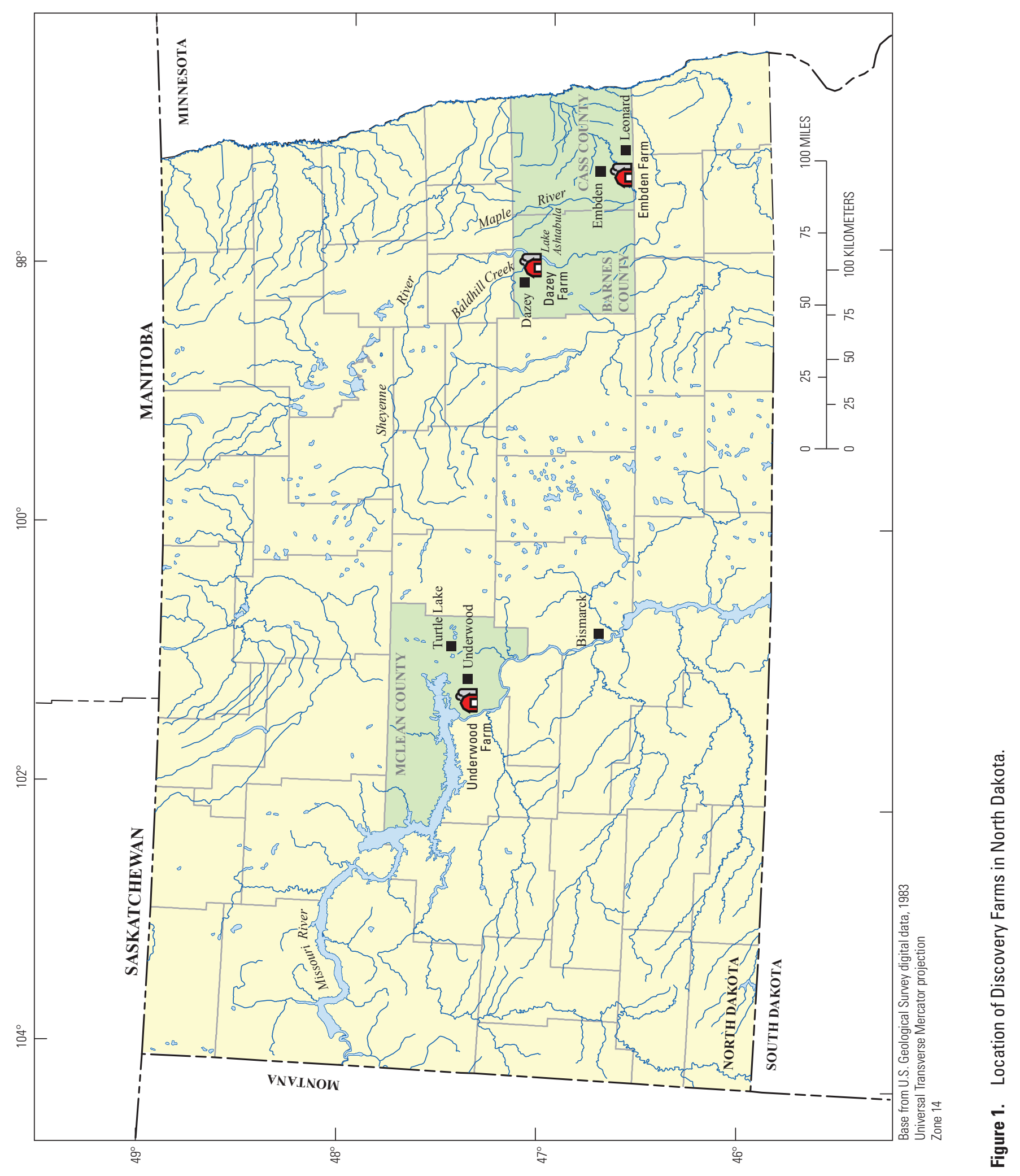




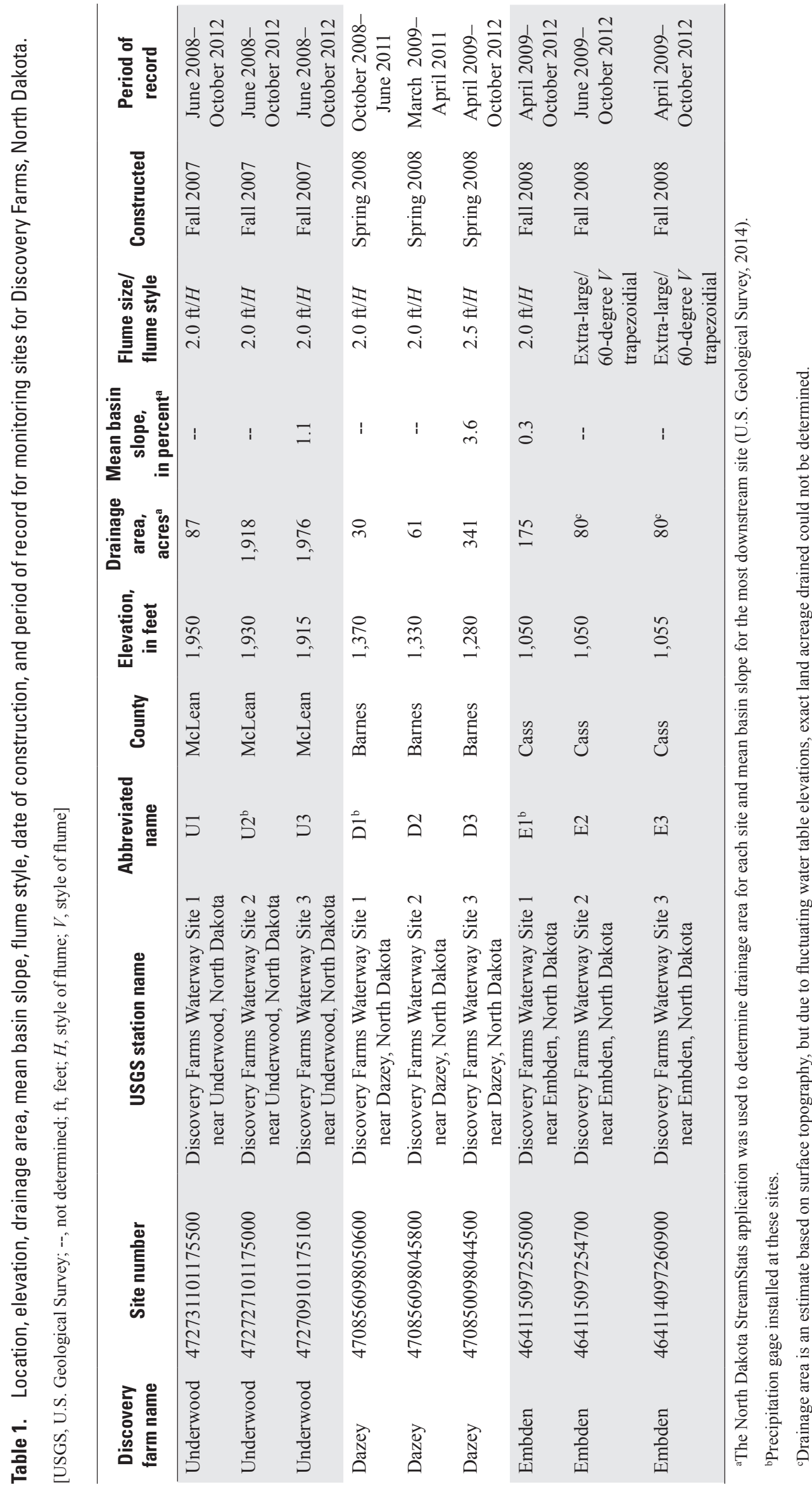



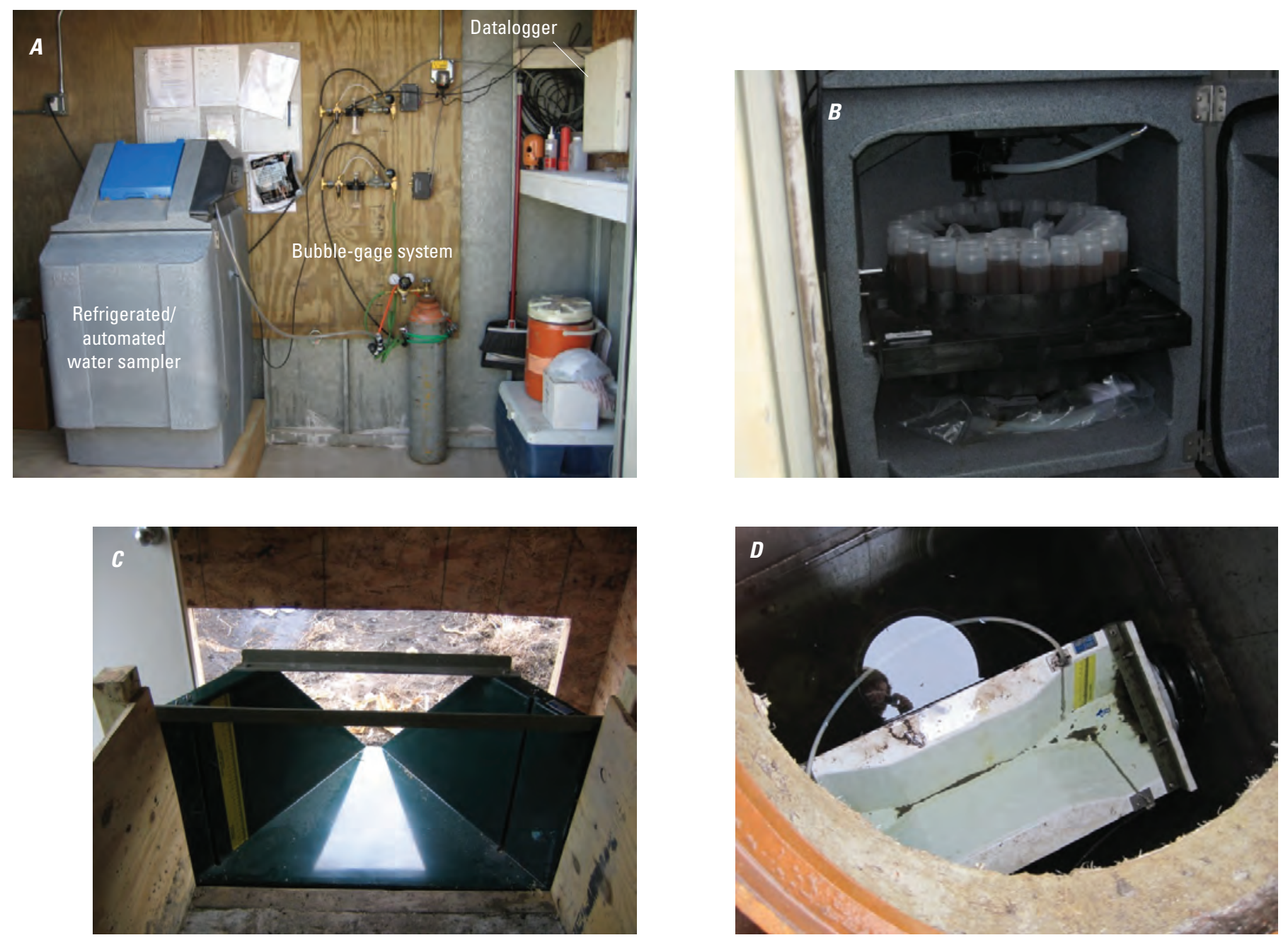

Figure 2. Equipment installed at Discovery Farms sites in North Dakota. $A$, Inside the gage house is a refrigerated automated water sampler, datalogger, bubble-gage system; $B, 24$ 1,000-milliliter sample bottles inside the water sampler; $C$, a 2.0 foot $H$ type flume; and $D$, an extra-large 60-degree $V$ type trapezoidal flume.

North Dakota (Bluemle and Biek, 2007). Although Embden Farm has a cattle operation, the data collection sites are located in an area only affected by runoff from cropland. Crops grown on the farm include corn, soybeans, wheat, and alfalfa. The soils vary from well-drained to somewhat poorly drained, and runoff is generally slow. Subsurface drainage tiles were installed in an agricultural field at the farm in 2009, and water from the drains can flow into the Maple River (fig. 5). The field being monitored has two separate subsurface drainage tile systems that drain the east and west halves of the field, respectively (fig. 5). Historically, the east and west fields have been treated as one unit; therefore, the two subsurface drainage tile systems provide a paired drainage system for comparative analyses. On the east field, most of the field surface drainage exits in the southeast corner of the field adjacent to the outlet for the east subsurface drainage system. Therefore, only two data shelters are required for the three data-collection sites at this farm. One shelter houses a data logger and two automated samplers (one for the surface drainage site [E1] and the other for a flume inserted into the drain tile outlet [E2]). The second shelter is located west of the first shelter and contains an automated water-quality sampler, a flume inserted into drain tile under the ground (E3), and a datalogger. The data shelters are located next to the edge of cropped fields along a township road. Drainage areas based on surface topography are provided in table 1, but because of fluctuating water table elevations the exact land acreage drained by the subsurface drainage sites could not be determined for sites E2 and E3.

\section{Methods}

Collection of discharge data, precipitation data, and water-quality samples began in June 2008 at Underwood Farm, October 2008 at Dazey Farm, and April 2009 at Embden Farm. Water-quality samples were collected during 


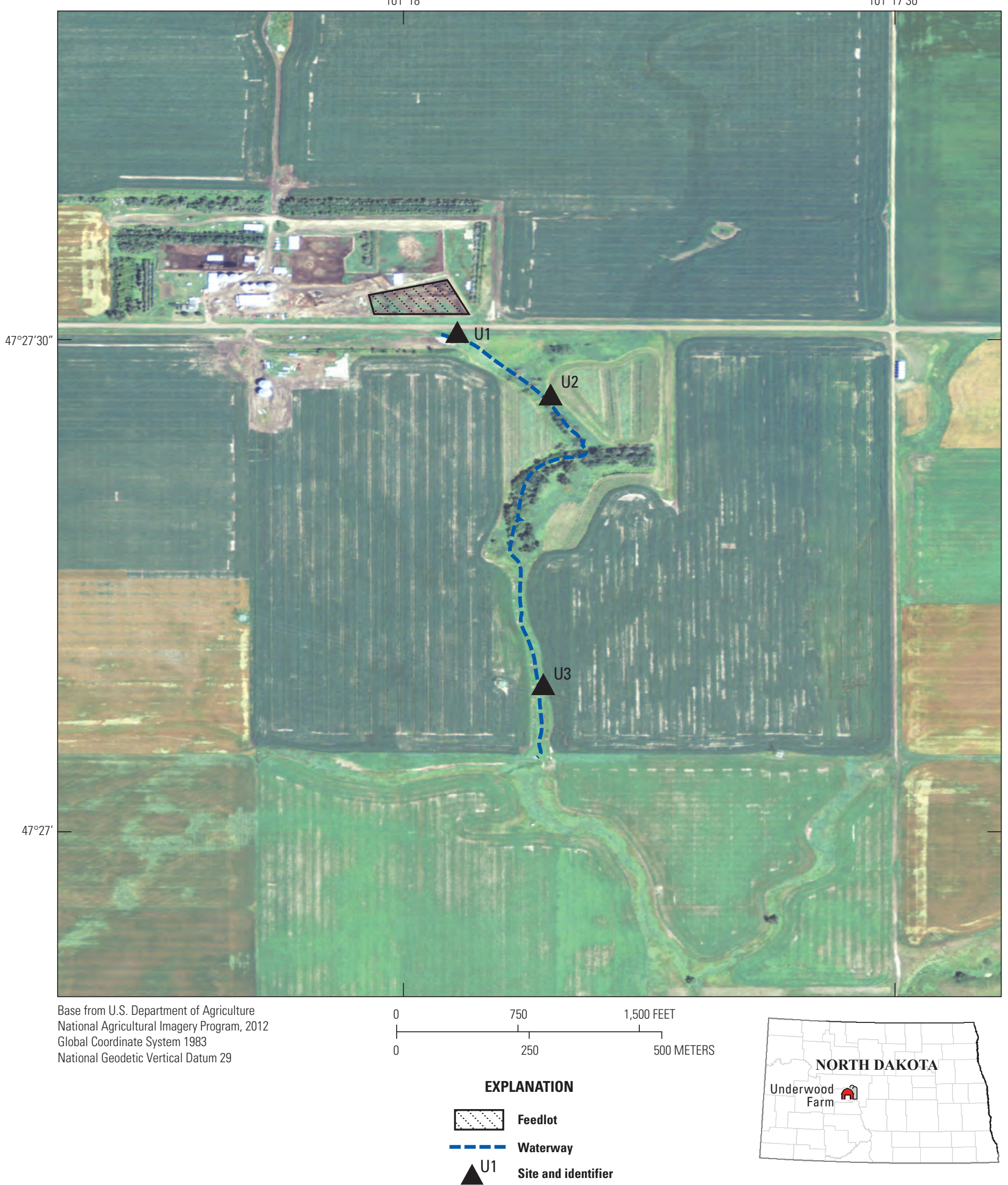

Figure 3. Location of monitoring sites and aerial view of Underwood Farm in North Dakota. 


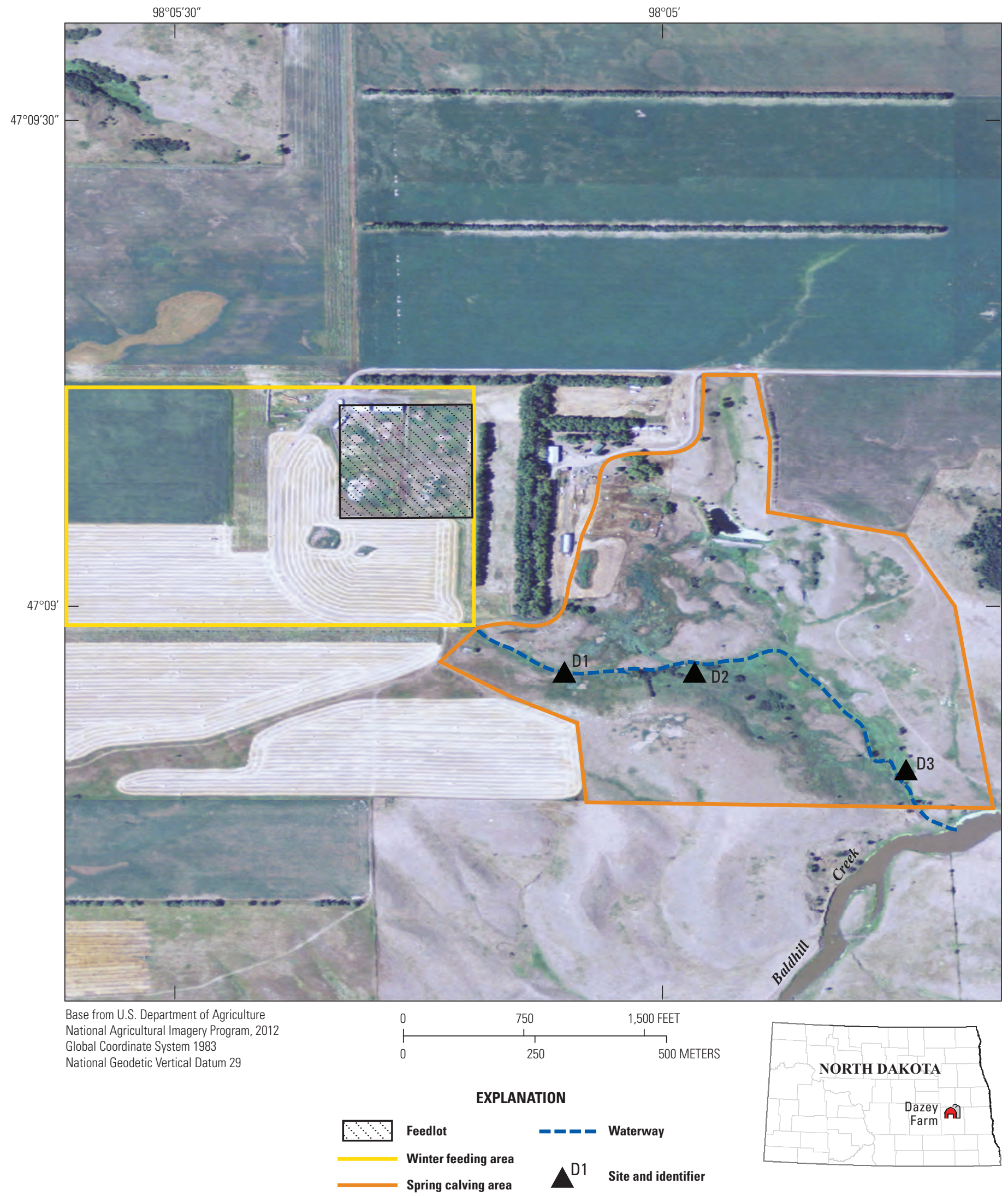

Figure 4. Location of monitoring sites and aerial view of Dazey Farm in North Dakota. 


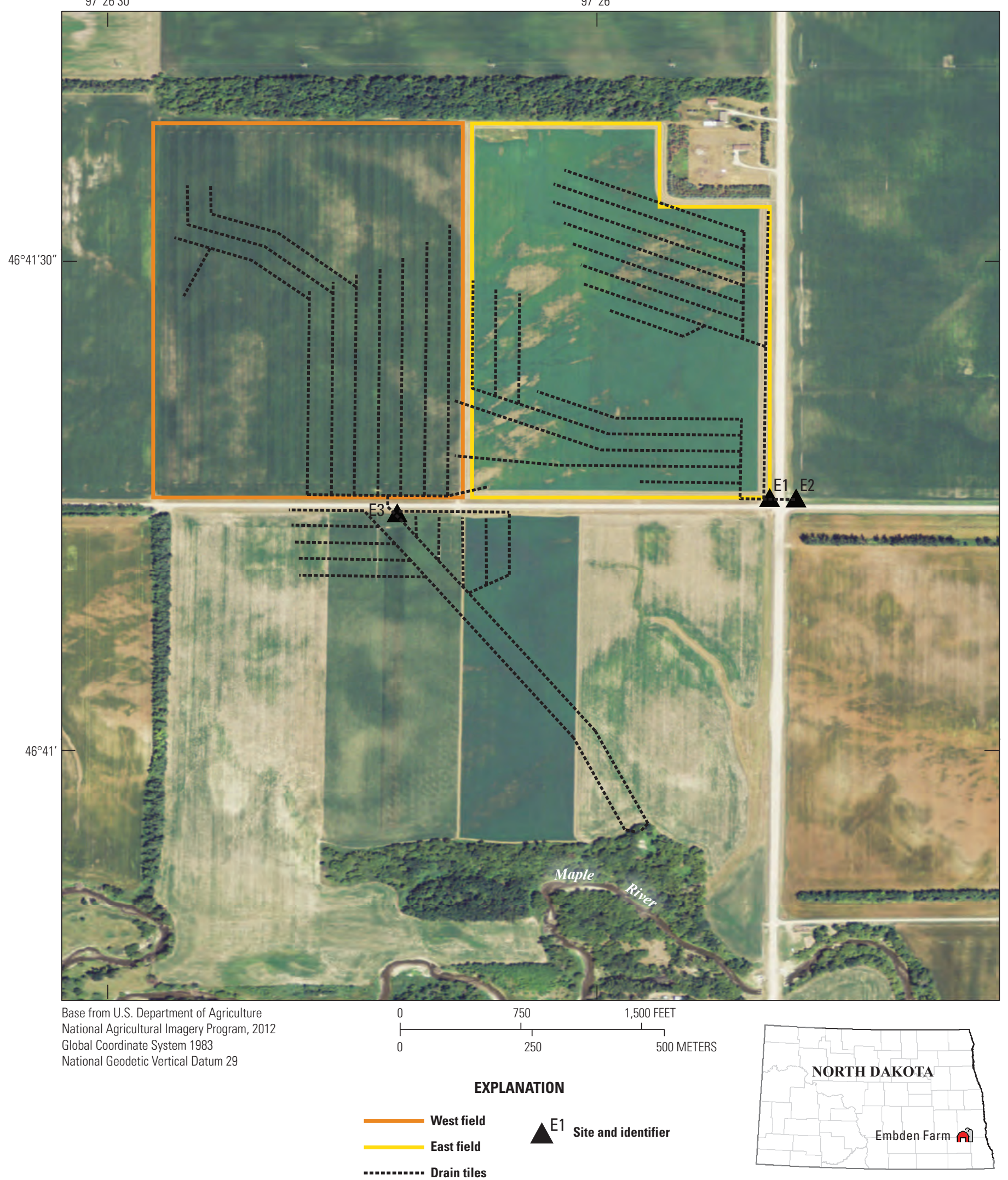

Figure 5. Location of monitoring sites and aerial view of Embden Farm in North Dakota. 
spring snowmelt and precipitation runoff events. Data analyses include annual and monthly summaries of precipitation and runoff data, summaries of water-quality concentrations, and computation of annual loads and yields.

\section{Data Collection}

Discharge data primarily were measured using flumes, but under some circumstances discharges had to be estimated. At each site, gage height was measured within the flume using the bubble-gage system (Sauer and Turnipseed, 2010). Discharge was calculated from gage height using an equation that was developed specifically for each flume type (Tracom, 2014a, 2014b, 2014c). Discharge was estimated during spring snowmelt because of ice and snow-affected gage heights. During the spring freeze-thaw cycle, ice dams and snow drifts in the flume caused pools of water around the flume resulting in erroneous gage-height values that translated into erroneous discharge values. Flumes were checked during site visits to determine if the recorded discharge values were reliable. When discharge values were deemed unreliable, discharge was estimated based on notes from site visits, temperature, and comparisons with other sites at the farm. Subsequent to the first year of data collection, discharge was collected in 15-minute increments and stored on the datalogger at each site.

Cellular telemetry was used to relay data to servers located at the USGS North Dakota Water Science Center in Bismarck, N. Dak. (fig. 1) for analysis and archiving. All data from the dataloggers were stored in the National Water Information System (NWIS; U.S. Geological Survey, 2013).

Precipitation data collected at U2, D1, and E1 were compared with the nearest North Dakota Agricultural Network (NDAWN) sites Dazey, Leonard, and Turtle Lake, respectively (fig. 1; North Dakota Agricultural Weather Network, 2013). At D1, missing data resulted in consistently low precipitation values compared with the Dazey NDAWN site, so annual and monthly precipitation data from the Dazey NDAWN site were used in this report to represent the Dazey Farm precipitation data. Precipitation collected from the farms sites and NDAWN sites were available from April through October because the gaging equipment located at these sites measures precipitation that falls as rain, and not snow. Estimates of precipitation for March 2008 and 2009 were obtained from the North Dakota State Climate Office (North Dakota State Climate Office, 2013b). Estimates of March precipitation for 2010 through 2012 were obtained from Community Collaborative Rain Hail and Snow Network (CoCoRaHS) sites located nearest each farm (Community Collaborative Rain Hail and Snow Network, 2013).

Depending on the site and the time of year, water-quality samples were collected using an automated water sampler or as a grab sample. The automated water samplers were programmed to collect a sample from the flume when certain criteria were met. Grab samples required a person to physically be on site to either fill up the sample bottle by hand or use the automated sampler to pump water into the sample bottle. For samples collected by the automated water sampler, the number of sampling bottles collected during a runoff event varied with the volume and duration of the event. A maximum of 24 bottles could be collected by an automated sampler during one runoff event. Water samples from the automated sampler were removed as soon as possible, and the full bottles were replaced with clean, empty bottles.

At Underwood Farm and Dazey Farm, most samples were collected by the automated water sampler during runoff events. Grab samples were collected for quality control, when the automated sampler was malfunctioning, or during the spring freeze-thaw cycle when ice dams in the flume created problems with sample collection. Automated water samplers were programmed to start sampling after a specific volume of water had passed through the flume. This specified volume of water was estimated based on possible rainfall amounts from showers and thunderstorms that were expected during the year. Although the automated sampler was programmed for a specified volume of water initially, the sampling frequency of the automated samplers could be adjusted during a runoff event. Repeated sampling was done when flow continued for a prolonged period of time. The frequency and duration of water sampling varied from site to site based on antecedent conditions, shelter location, and runoff event. Sample times, discharge at time of sample, number of bottles filled, and other information pertaining to the sampling event was stored on the datalogger.

At Embden Farm, nearly all samples were collected as grab samples. At the surface drainage site, E1, grab samples were collected by hand because the majority of runoff happens in the spring and the flume is readily accessible. For the two subsurface drainage sites, E2 and E3, grab samples were collected because runoff lasts several days to weeks. At site E2, grab samples were collected by hand. At site E3, the automated sampler was used to pump water into the sample bottle because the flume was difficult to access.

Water-quality samples were analyzed by the North Dakota State Department of Health Division of Laboratory Services according to methods and procedures described in Clesceri and others (1999) or the U.S. Environmental Protection Agency (2013a). Samples were analyzed for chloride, total ammonia plus organic nitrogen, total ammonia, nitrate plus nitrite plus nitrogen, total nitrogen, and total phosphorus. For all samples, concentration analyses for chloride were made from filtered samples, and analyses for other constituents were made from unfiltered samples. Starting in spring of 2010 , filtered samples also were analyzed to determine nutrient concentrations. Nutrient concentrations of filtered samples are not presented in this report, but are available in the USGS NWIS database (U.S. Geological Survey, 2013). Because of known biases, not all analyzed forms of nitrogen are presented in this report. Total ammonia plus organic nitrogen concentrations are not presented. Total nitrogen concentrations are summarized but not used to compute loads or yields, and organic nitrogen is expressed as a percent. Total nitrogen was analyzed 
using alkaline-persulfate digestion, which has been determined to be negatively biased in the presence of sediment concentrations (Rus and others, 2013). Because laboratory results of total ammonia plus organic nitrogen was a calculated value based on the difference of total nitrogen and nitrate plus nitrite nitrogen, results also are biased. Although total nitrogen was known to be biased, to estimate the speciation of nitrogen at a farm, total nitrogen was used in expressing organic nitrogen, ammonia nitrogen, and nitrate plus nitrite nitrogen as a percentage of total nitrogen. For surface drainage sites, U1-3, D1-3, and E1, samples also were analyzed for suspendedsediment concentration by the USGS Iowa Water Science Sediment Laboratory in Iowa City, Iowa, following procedures described in Guy (1969). All water-quality data collected in this study were stored in the USGS NWIS database (U.S. Geological Survey, 2013).

\section{Data Presentation and Analysis}

Annual and monthly mean precipitation and runoff data were presented from March through October for 2008 through 2012. Annual precipitation for each farm was compared with the 30 -year mean annual precipitation. For a given year, data for each site were presented from March 1 through October 31. Runoff was computed for sites U1-3, D3, and E1 but runoff could be not computed for D1 and D2 because not enough discharge data were collected. For subsurface tile drainage sites, E2 and E3, runoff was estimated from surface drainage area, but because of uncertainty in the drainage area, runoff was not compared with other sites. For water-quality constituents, statistical summaries of the maximum; minimum; and 10th, 25th, 50th, 75th, and 90th percentiles were computed and presented graphically using boxplots. The boxplots were then used to compare concentrations of selected water-quality constituents. Boxplots of suspended sediment concentrations were not presented for Embden Farm because suspended sediment samples were not collected at the subsurface tile drainage sites (E2 and E3), and only a few samples were collected at the surface drainage site at Embden Farm (E1). In the case of censored data (data that contains values less than the laboratory reporting levels), the nonparametric Kaplan-Meier statistical method was used to estimate the statistical summary (Helsel, 2005). Concentrations were tested for differences among sites using the Wilcoxon rank sum test (Helsel and Hirsch, 2002). The Wilcoxon rank sum test is a nonparametric test that determines the probability (p) that the distribution of the dataset is similar to the distribution set within a selected level of significance. Because many comparisons were made, for this report, a level of significance of 0.01 $(\alpha=0.01)$ was selected. Although likely underestimated, total nitrogen concentrations were used to estimate the speciation of nitrogen in the runoff at the Discovery Farms. Ammonia and nitrate plus nitrite nitrogen as a percentage of total nitrogen was computed. The percentages of ammonia and nitrate plus nitrite were then summed and subtracted from 100, and the remaining percentage was estimated to be organic nitrogen.

Daily loads were computed for sites using estimated daily mean values of constituent concentration and discharge data for the periods of record from select Discovery Farm sites. For each day of existing records, values of constituent concentration and 15-minute discharge were averaged arithmetically to produce estimated daily-mean constituent concentrations and discharges. For days without existing records, daily-mean constituent concentrations were estimated using linear interpolation, and daily-mean discharge values were estimated using data from the other sites at the farms or from other ancillary information. Daily loads (L) were estimated using the dailymean concentrations $(\mathrm{C})$ and discharges $(\mathrm{Q})$ according to the equation:

$$
L=5.39 \times C \times Q,
$$

where
$L \quad$ is the daily constituent load, in pounds per day;
5.39 is the conversion factor used to convert units of milligrams per liter and cubic feet per second to units of pounds per day;
$C$ is the daily mean constituent concentration, in milligrams per liter; and
$Q \quad$ is the daily mean discharge, in cubic feet per second.

\section{Quality Assurance and Quality Control}

Water-quality samples were collected by USGS personnel with assistance from cooperating agencies. Equipment used for sampling was calibrated according to manufacturer's specifications and periodically checked in the field. Upon each visit to the data shelters, equipment was inspected for malfunctions to ensure valid samples were being collected. Also, field instruments were cleaned periodically according to instructions and protocols from the USGS, North Dakota State Department of Health, and instrument manufacturers (U.S. Geological Survey, variously dated; Stuntebeck and others, 2008).

Blank and replicate samples were collected to estimate the variability in the laboratory analysis and reproducibility in the collection of samples. A total of three blank samples were collected and analyzed for chloride and nutrients. All constituents for blank samples were near or less than the laboratory reporting level. Thirty-one replicate samples were collected and analyzed for chloride, total phosphorus, total ammonia, and nitrate plus nitrite. For suspended sediment, nine replicate samples were collected and analyzed. The analytical variability of replicate samples for constituents other than suspended sediment was small with average differences ranging from 3.5 percent for chloride to 12.9 percent for total phosphorus. 
The average difference for suspended sediment was 19.8 percent (table 2). Higher variability in replicate suspended sediment samples likely is related to natural variability in runoff concentrations. Results from quality assurance and quality control data indicate that cleaning procedures were adequate to prevent cross-contamination of samples, and laboratory results were reproducible.

Table 2. Results of quality-assurance samples for chloride, nutrient and suspended-sediment concentrations for samples collected for Discovery Farms, 2008-12.

[Calculation of percent difference is:|( $\left.x_{1}-x_{2}\right) /\left(x_{1}+x_{2}\right) / 2 \mid(100)$, where $x_{1}=$ sample, $x_{2}=$ sequential replicate; $\mathrm{N}$, nitrogen]

\begin{tabular}{lcc}
\hline \multicolumn{1}{c}{ Constituent } & Number of samples & $\begin{array}{c}\text { Average percent } \\
\text { difference }\end{array}$ \\
\hline Chloride & 31 & 3.5 \\
Suspended sediment & 9 & 19.8 \\
Total phosphorus & 31 & 12.9 \\
Total ammonia as N & 31 & 6.0 \\
Nitrate plus nitrite & 31 & 12.7 \\
\hline
\end{tabular}

\section{Precipitation, Flow Volume, and Runoff}

Precipitation, flow volume, and runoff data collected at all three farms were used to understand factors affecting runoff from agricultural fields. Annual statistics presented below are based on data from March through October. Annual statistics were computed only if data were available for the entire period from March through October. Flow volume is presented to compare surface drainage sites with the two drainage tile sites at the Embden Farm. Runoff is presented in inches only for surface drainage sites. An estimate of runoff for the subsurface drainage tile sites at Embden Farm computed from surface area drainage indicates that groundwater is a component of the runoff at $\mathrm{E} 2$ and $\mathrm{E} 3$.

\section{Annual Precipitation, Flow Volume, and Runoff}

Annual precipitation (March through October) was lowest in 2012 and highest in 2010 ranging from 11.08 in. at Underwood Farm in 2012 to 26.6 in. at Embden Farm in 2010 (fig. 6). For all farms, the annual precipitation in 2010 was greater than the 30-year mean annual precipitation (March through October of 1981-2010) of 17.94 in. In 2011, the

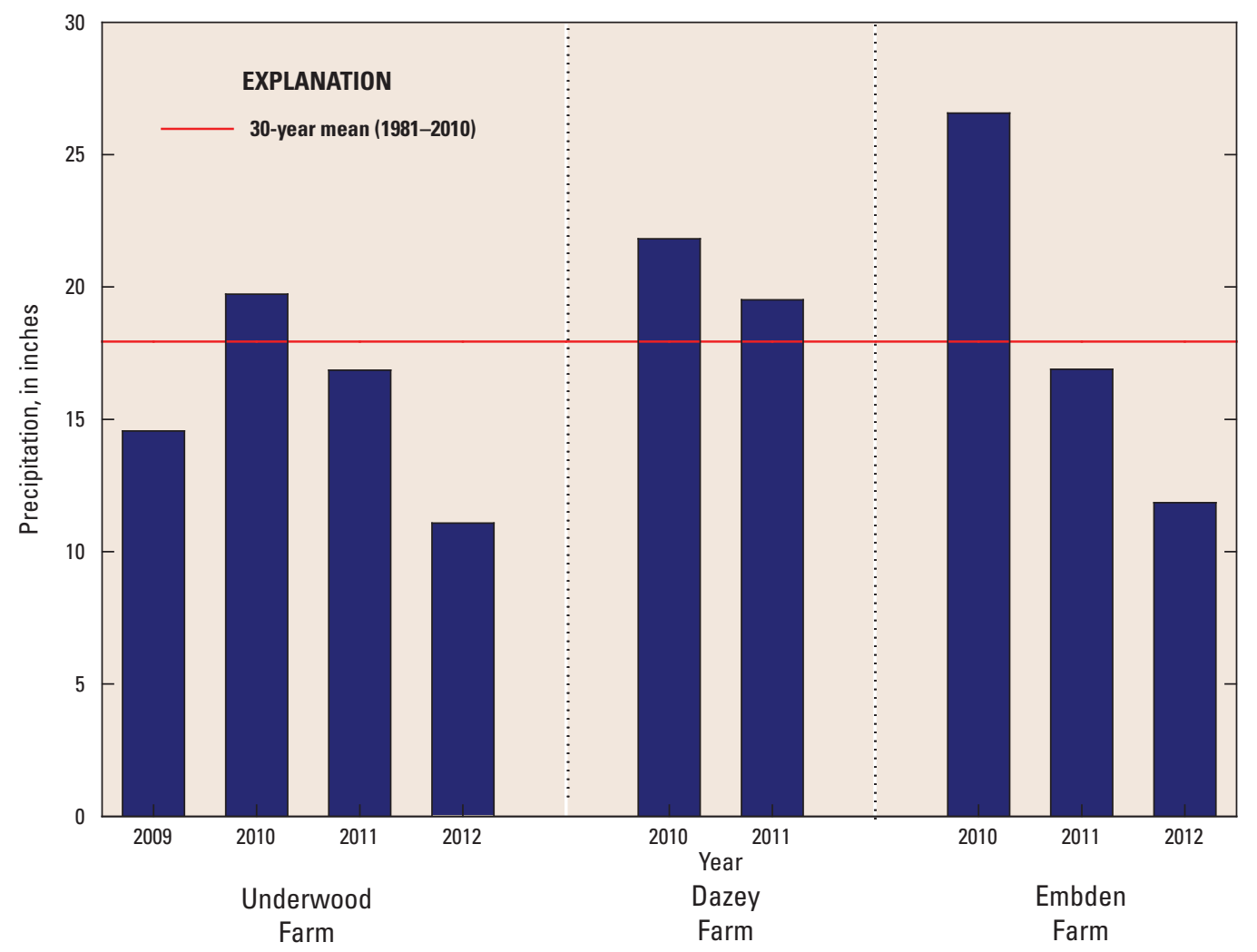

Figure 6. Annual precipitation for Discovery Farms in North Dakota from March through October (2009-2012) and 30-year mean annual precipitation (1981-2010); the 30-year mean annual is an average of National Weather Service sites located near the Underwood, Dazey, and Embden Farms from March through October (North Dakota Agricultural Network, 2012). 
annual precipitation for all the farms was within 20 percent of the 30-year mean, but in 2012 the annual precipitation for Underwood and Embden Farms was well below the 30-year mean.

Similar to precipitation, the annual flow volume (March through October) was lowest in 2012 (fig. 7). For all years at farm sites, annual flow volumes ranged from 0.17 million gallons (Mgal; E2, 2012) to $56 \mathrm{Mgal}(\mathrm{E} 3,2010)$. Annual flow volume was largest in 2010 for Dazey and Embden Farms, but largest in 2011 for Underwood Farm. At Underwood Farm, the largest volume for all the years $(34.3 \mathrm{Mgal})$ was at the most downstream site, U3, in 2011 (fig. 7). The large flow volumes in 2010 and 2011 at E2 and E3 likely are related to consecutive years of near average precipitation. Wet fall periods in 2009 and 2010 caused the subsurface drainage sites (E2 and E3) to have flow through the winter. Flow for the subsurface drainage sites (E2 and E3) from November through February is not included in figure 7 , but ranged from about 3 to 6.9 Mgal.

Annual runoff for all surface drainage sites averaged 1.3 inches or 7.6 percent of the annual precipitation (fig. 8), which is slightly lower than the annual runoff of 2.6 in. or 8.0 percent of the annual precipitation reported for Discovery Farms in Wisconsin (Stuntebeck and others, 2011). Annual runoff for all surface drainage sites (U1-3, D3, and E1) ranged from less than 0.1 in. in 2012 at $\mathrm{U} 2, \mathrm{U} 3$, and $\mathrm{E} 1$ to $6.0 \mathrm{in}$. at U1 in 2011, and percentage of runoff varied from less than
0.1 percent at $\mathrm{U} 2, \mathrm{U} 3$, and $\mathrm{E} 1$ in 2012 to 35 percent at $\mathrm{U} 1$ in 2011 (fig. 8). Although 2010 had the highest annual precipitation for all farms, the highest annual runoff for Underwood and Embden Farms was in 2011 (figs. 6 and 8). Precipitation, rainfall intensity, and soil condition (antecedent moisture, frozen, or thawed) likely were important factors that affected annual runoff (Stuntebeck and others, 2011). Because of subsurface drainage tiles and lower slope (table 1), soil conditions more likely affect runoff at the Embden Farm surface drainage site (E1) than the other surface drainage sites. At E1, precipitation has to be continuous and persistent for runoff to be measureable. In contrast, rainfall intensity likely affects runoff more than soil condition at surface drainage sites at Dazey (D1-3) and Underwood (U1-3) Farms because of steeper slope (table 1) than E1 and lack of subsurface drainage tiles.

Runoff based on surface drainage area was estimated to illustrate the effect of groundwater on flow measured at the subsurface drainage tiles (E2 and E3, table 3). Based on calculated estimates, runoff at E2 and E3 is greater than three times the highest year of runoff for the surface drainage sites (fig. 8). Furthermore, in 2011, calculated runoff exceeds precipitation. Physically, runoff cannot exceed precipitation. For E2 and E3, the surface drainage area does not account for all of the contributing area. Groundwater clearly is a component of the flows measured at E2 and E3, but the amount of flow attributed to groundwater was not investigated for this study.

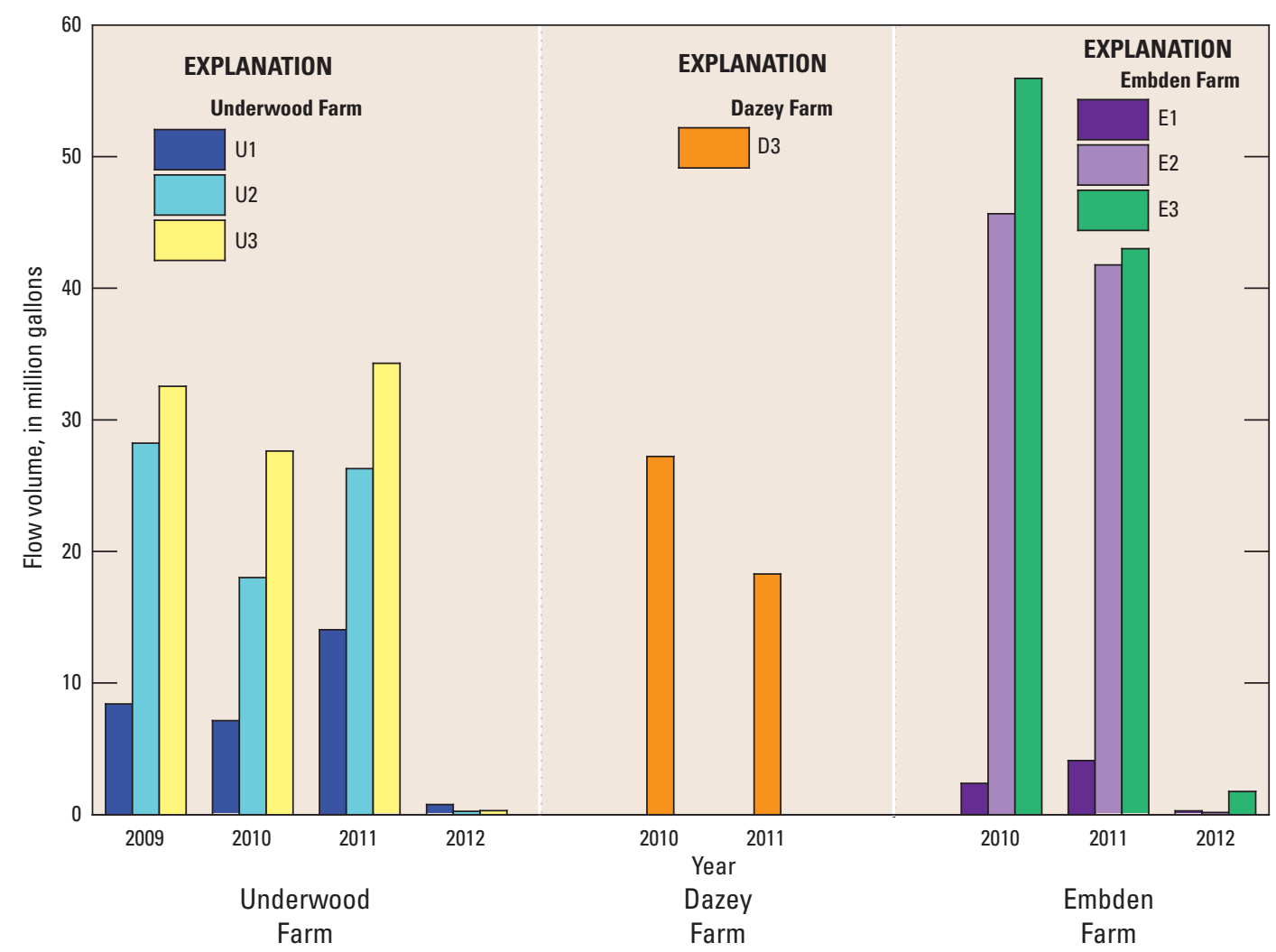

Figure 7. Flow volume for Discovery Farms in North Dakota from March through October, 2009-2012. 

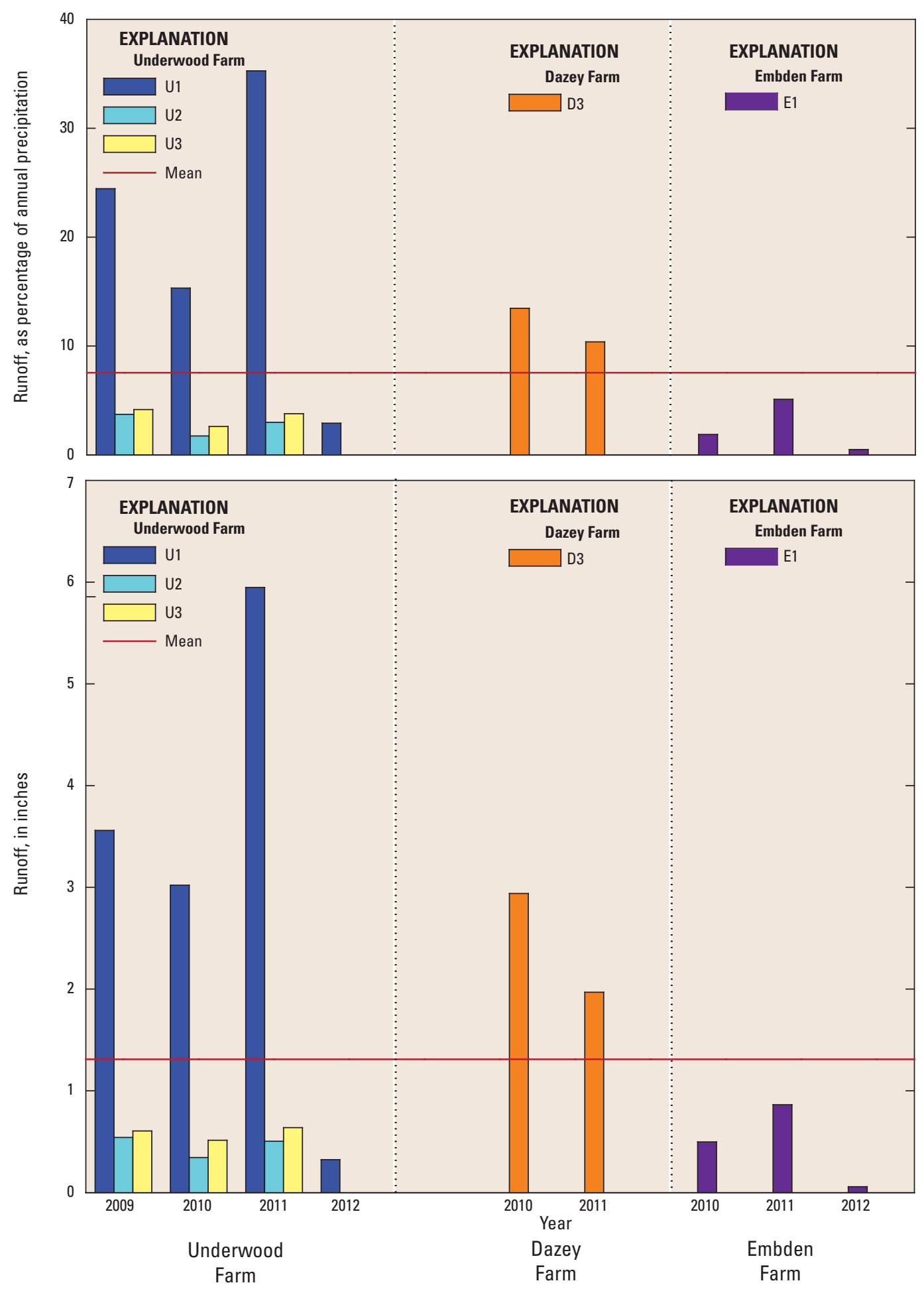

Figure 8. Annual runoff and runoff as a percentage of annual precipitation for Discovery Farms in North Dakota from March through October 2009-2012. 
Table 3. Estimate of runoff for subsurface drainage tile sites, E2 and E3, using surface drainage area at Embden Farm, 2010-12.

\begin{tabular}{|c|c|c|c|c|c|}
\hline \multirow[b]{2}{*}{ Year } & \multirow{2}{*}{$\begin{array}{l}\text { Precipitation } \\
\text { (inches) }\end{array}$} & \multicolumn{2}{|r|}{ E2 } & \multicolumn{2}{|c|}{ E3 } \\
\hline & & $\begin{array}{l}\text { Runoff } \\
\text { (inches) }\end{array}$ & $\begin{array}{l}\text { Runoff as a percentage of } \\
\text { precipitation }\end{array}$ & $\begin{array}{l}\text { Runoff } \\
\text { (inches) }\end{array}$ & $\begin{array}{c}\text { Runoff as a percentage of } \\
\text { precipitation }\end{array}$ \\
\hline 2010 & 26.6 & 21.0 & 79.2 & 24.0 & 89.0 \\
\hline 2011 & 16.9 & $19.2^{\mathrm{a}}$ & 114 & $18.8^{\mathrm{a}}$ & 111 \\
\hline 2012 & 11.9 & 0.10 & 0.60 & 0.81 & 6.80 \\
\hline
\end{tabular}

aPhysically, runoff cannot exceed precipitation. For these sites, the surface drainage area does not account for all of the contributing area. Groundwater is clearly a component of the runoff.

\section{Monthly Precipitation and Runoff}

Monthly precipitation was highly variable ranging from 0.14 in. at Embden Farm in September 2011 to 6.6 in. at Dazey Farm in May of 2010 (fig. 9). For most years, monthly precipitation for all the farms was highest in May, June, or July with the highest monthly mean precipitation of about 3.5 in. in June for all farms (fig. 9). With the exception of 2010, precipitation generally was lowest in September or October. For the Dazey and Embden Farms, the monthly mean precipitation was lowest in October at less than 2 in. For the Underwood Farm, monthly mean precipitation was lowest in September at about 1.3 in.

The highest amount of runoff was observed in March, which relates to snowmelt, and is different from patterns in precipitation (fig. 10). In North Dakota, little, if any, snow melts between November and March, and therefore most of the winter precipitation is included in March runoff. At Underwood and Embden Farms, monthly runoff was highest in March 2011, and at Dazey Farm, monthly runoff was highest in March of 2010 (fig. 10). At all three farms, substantial runoff was observed in April of 2011 because of above average precipitation in the winter of 2010-2011 and a later spring thaw (North Dakota State Climate Office, 2013a). Monthly mean runoff was highest in March ranging from about 0.3 in. at Embden Farm to about 1 in. at Dazey Farm. In contrast, monthly mean runoff was generally lowest in August through October at most farms (fig. 10).

\section{Water-Quality Characteristics}

Concentrations of chloride, suspended sediment, total phosphorus, and several forms of nitrogen (total ammonia, nitrate plus nitrite nitrogen, and total nitrogen) collected between June 2008 through October 2012 for all sites and all farms are presented below. The number of samples collected from 2008 through 2012 varied from 17 at D2 to 152 at U1 (table 4). The number of samples collected each year was affected by precipitation and equipment malfunctions. Suspended sediment concentrations are not presented for Embden Farm because suspended sediment samples were not collected at the subsurface tile drainage sites (E2 and E3), and few samples were collected at the surface drainage site at Embden (E1).
Loads for chloride, suspended sediment, total phosphorus, ammonia, and nitrate plus nitrite were computed for sites and years in which a complete year (March through October) of data was available. For the Underwood Farm, loads were presented for all three sites, U1, U2, and U3, for 2009 through 2012. For Dazey Farm, loads were presented for D3 for 2010 and 2011. For the Embden Farm, loads were presented for E1, E2, and E3 for 2010, 2011, and 2012. For surface drainage sites, U1, U2, U3, D3, and E1, yields for chloride, suspended sediment, total phosphorus, ammonia, and nitrate plus nitrite were computed for the same time periods as for loads.

\section{Water Quality by Farm}

Water-quality characteristics for sites within the same farm are compared in the section below. Within the same farm, differences in water quality among sites are evident, and consistent patterns generally emerged from the data. Among the farms, similarities also were observed.

\section{Underwood Farm}

At Underwood Farm (fig. 1), concentrations generally decreased from upstream to downstream because of proximity to the feedlot and grassy depressions located between sites (fig. 11). For all constituents, the maximum concentration was observed at the upstream site (U1), which is the site closest to the feedlot (fig. 11). With the exception of nitrate plus nitrite, a statistically significant decrease in concentration from upstream to downstream generally was observed (fig. 11). Median suspended sediment concentrations decreased an order of magnitude ranging from 444 milligrams per liter $(\mathrm{mg} / \mathrm{L})$ at U1 to $49 \mathrm{mg} / \mathrm{L}$ at U3, and median total phosphorus concentrations decreased from $11.4 \mathrm{mg} / \mathrm{L}$ at $\mathrm{U} 1$ to $3.67 \mathrm{mg} / \mathrm{L}$ at $\mathrm{U} 3$. Proximity to the feedlot resulted in higher suspended sediment and total phosphorus concentrations at U1. At U2 and U3, less concentrated runoff from surrounding crop land likely caused some dilution. Total phosphorus is a measure of both the phosphorus that is attached to suspended sediment particles (particulate phosphorus) and biologically available phosphorus (dissolved phosphorus; Minnesota Pollution Control Agency, 2007). In the grassy depressions between sites, particulate phosphorus likely was removed from sediment settling out, and dissolved phosphorus likely was removed by vegetation. 

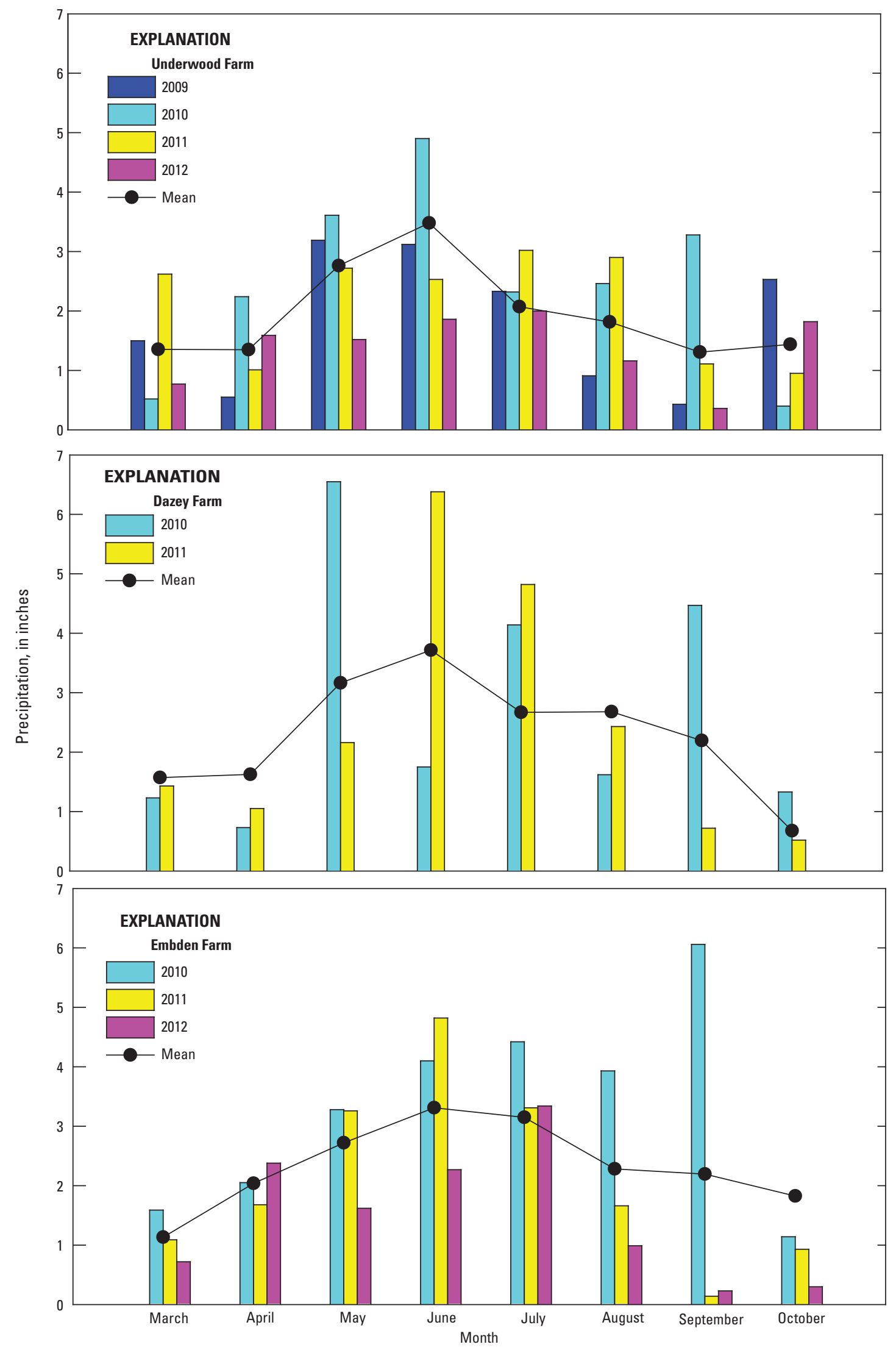

Figure 9. Monthly precipitation and monthly mean precipitation for Discovery Farms in North Dakota, 2009-2012. 

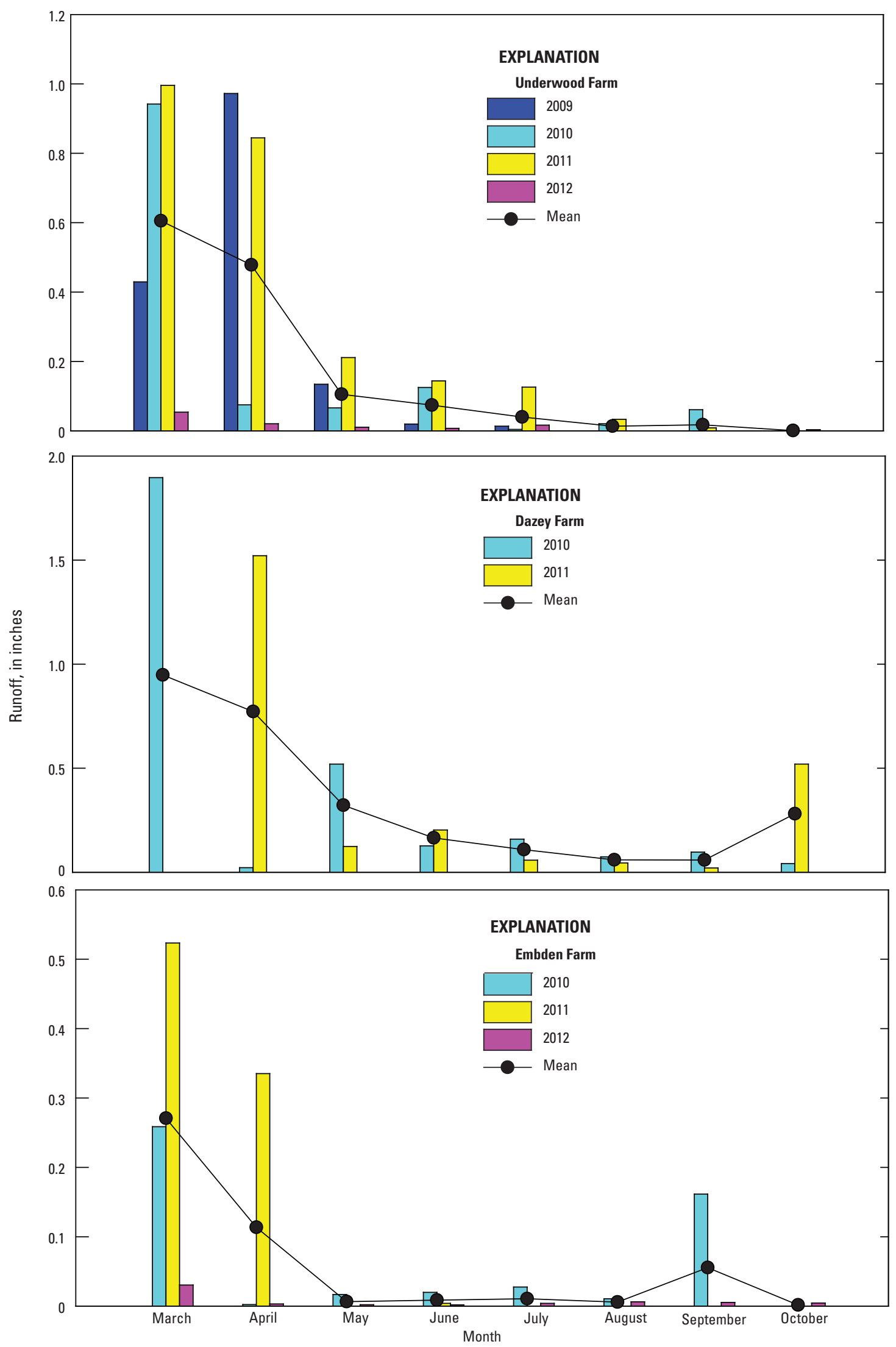

Figure 10. Monthly runoff and monthly mean runoff for surface drainage sites at Discovery Farms in North Dakota, 2009-2012. 
Table 4. Number of samples collected each year for Discovery Farms sites, June 2008-0ctober 2012.

\begin{tabular}{|c|c|c|c|c|c|c|}
\hline \multirow{2}{*}{ Site } & \multicolumn{5}{|c|}{ Year } & \multirow{2}{*}{ Total } \\
\hline & 2008 & 2009 & 2010 & 2011 & 2012 & \\
\hline \multicolumn{7}{|c|}{ Underwood Farm } \\
\hline U1 & 22 & 36 & 36 & 29 & 29 & 152 \\
\hline U2 & 18 & 27 & 40 & 23 & 4 & 112 \\
\hline U3 & 8 & 25 & 27 & 18 & 3 & 81 \\
\hline \multicolumn{7}{|c|}{ Dazey Farm } \\
\hline D1 & 6 & 2 & 14 & 8 & 0 & 30 \\
\hline D2 & 0 & 3 & 13 & 1 & 0 & 17 \\
\hline D3 & 0 & 6 & 19 & 17 & 5 & 47 \\
\hline \multicolumn{7}{|c|}{ Embden Farm } \\
\hline E1 & 0 & 3 & 18 & 4 & 2 & 27 \\
\hline E2 & 0 & 12 & 35 & 18 & 1 & 66 \\
\hline E3 & 0 & 9 & 44 & 19 & 7 & 79 \\
\hline
\end{tabular}

For chloride, ammonia, and total nitrogen, concentrations decreased from U1 to U2, but were not significantly different between U2 and U3 (fig. 11). Higher chloride at U1 may be the result of chloride in feedlot manure caused by feed additives (Mullaney and others, 2009). Organic nitrogen and ammonia are the primary forms of nitrogen in manure, which likely caused higher total nitrogen (total nitrogen includes organic nitrogen) and ammonia concentrations at U1 (U.S. Environmental Protection Agency, 2013b). Some of the decrease in chloride, ammonia and total nitrogen concentrations between $\mathrm{U} 1$ and $\mathrm{U} 2$ likely is attributed to dilution. For ammonia, nitrification (conversion of ammonia to nitrite, and then nitrate under aerobic conditions) likely is reducing ammonia concentrations between $\mathrm{U} 1$ and $\mathrm{U} 2$, but contributing nitrate plus nitrite to U2. Different from the other constituents, nitrate plus nitrite concentrations were not significantly different among sites (fig. 11). Little nitrate is lost from the landscape through surface runoff, and nitrate is highly soluble, which causes it to be leached from soil or to flow through soil into groundwater (Randall and Mulla, 2011). In addition, nitrate plus nitrite is biologically available, and is affected by nitrification and denitrification (the conversion of nitrate to nitrogen gas under anoxic conditions; U.S. Environmental Protection Agency, 2013b). For nitrate plus nitrite, the surface runoff processes that dominated other constituents (dilution, settling out, vegetative uptake) were moderated by other processes specific to nitrate plus nitrite (high solubility, nitrification, and denitrification) resulting in no significant change in concentrations from upstream to downstream. For constituents other than nitrate plus nitrite, dilution, settling out of sediment particles, and vegetative uptake likely contributed to the decrease in constituent concentration from upstream to downstream.

As previously discussed in the Data Presentation and Analysis section, although total nitrogen concentrations were likely underestimated, they were used to estimate the speciation of nitrogen in the runoff at the Discovery Farms. The predominant form of nitrogen at Underwood Farm was organic nitrogen (59 percent of total nitrogen; fig. 12), which is consistent with surface drainage sites at Discovery Farms in Wisconsin (Drummy and others, 2011).

Consistent with constituent concentrations of chloride, suspended sediment, total phosphorus, and ammonia, the largest loads typically were observed at U1 and the smallest loads were observed at U3 (figs. 11 and 13). In contrast, for nitrate plus nitrite, the smallest load of about 7 pounds (lb) were observed at $\mathrm{U} 2$ and the largest load of $350 \mathrm{lb}$ were observed at U3 (fig. 13). Consistent with annual flow volumes, for constituents other than nitrate plus nitrite, the smallest annual loads were in 2012, and the largest annual loads were in 2011 (figs. 7 and 13). Although the largest nitrate plus nitrite loads generally were observed in 2010, 2011 was the year with the largest amount of flow volume (figs. 7 and 13). Because nitrate is highly soluble and easily leaches through the soil profile, not only does flow volume affect the loading of nitrates into surface drainage, but the temporal distribution of flow volume within a year also has an effect (Randall and Mulla, 2001). At Underwood Farm in 2010, April, May, and June were wetter than any of the other years (fig. 9). In spring and early summer, less storage capacity in the soil combined with low evapotranspiration losses contribute to drainage water with higher nitrates (Randall and Mulla, 2001). The temporal distribution of precipitation may have contributed to the larger nitrate plus nitrite loads in 2010.

Similar to loads, with the exception of nitrate plus nitrite, the largest annual yields were in 2011 at the most upstream site (U1) and the smallest annual yields were in 2012 at the most downstream site (U3) (fig. 14). In 2011, annual precipitation was nearly 3 in. less than 2010 (fig. 6), but 2011 annual yields for chloride, total phosphorus, suspended sediment, 


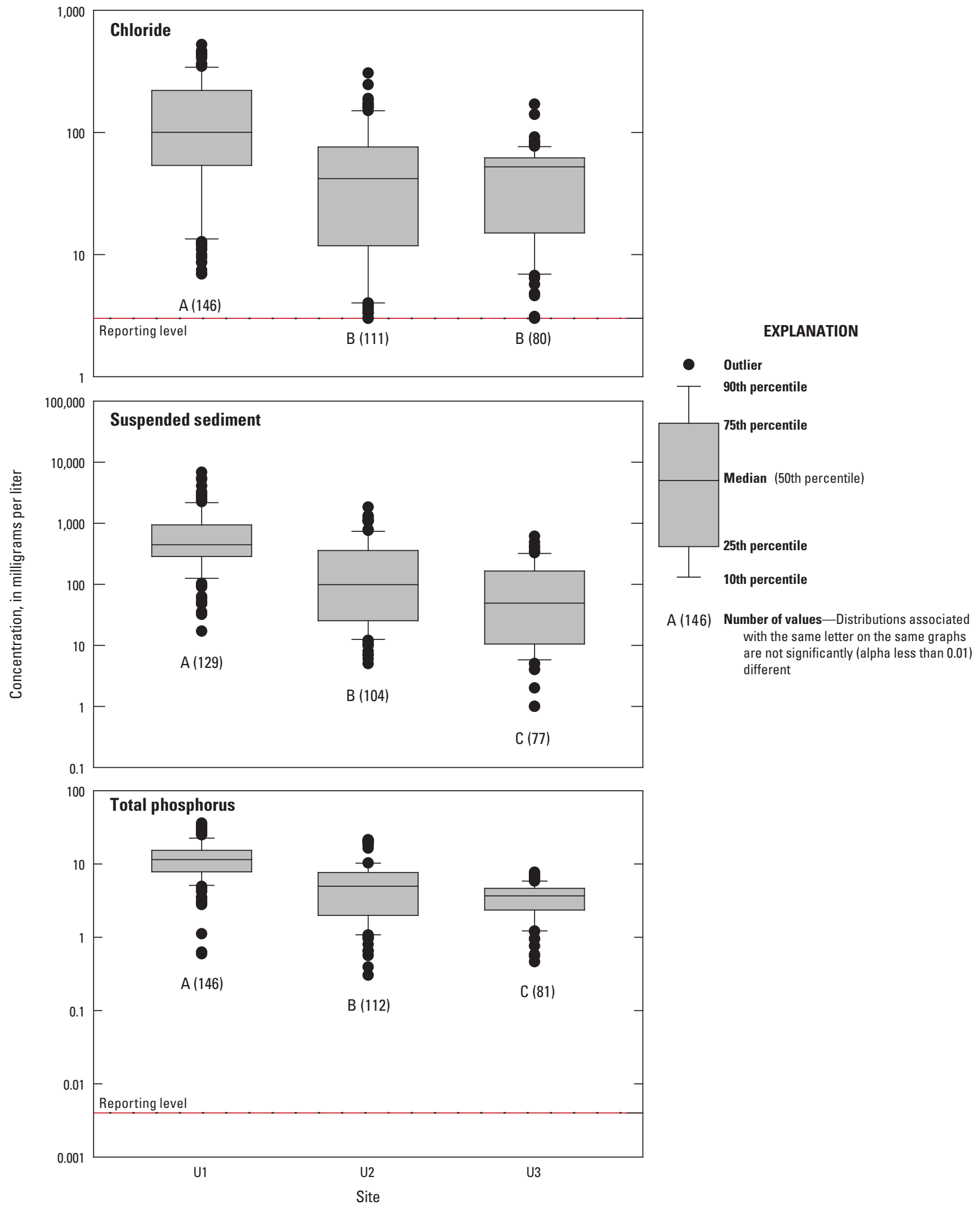

Figure 11. Distribution of constituent concentrations at Underwood Discovery Farms, North Dakota, 2008-2012. 

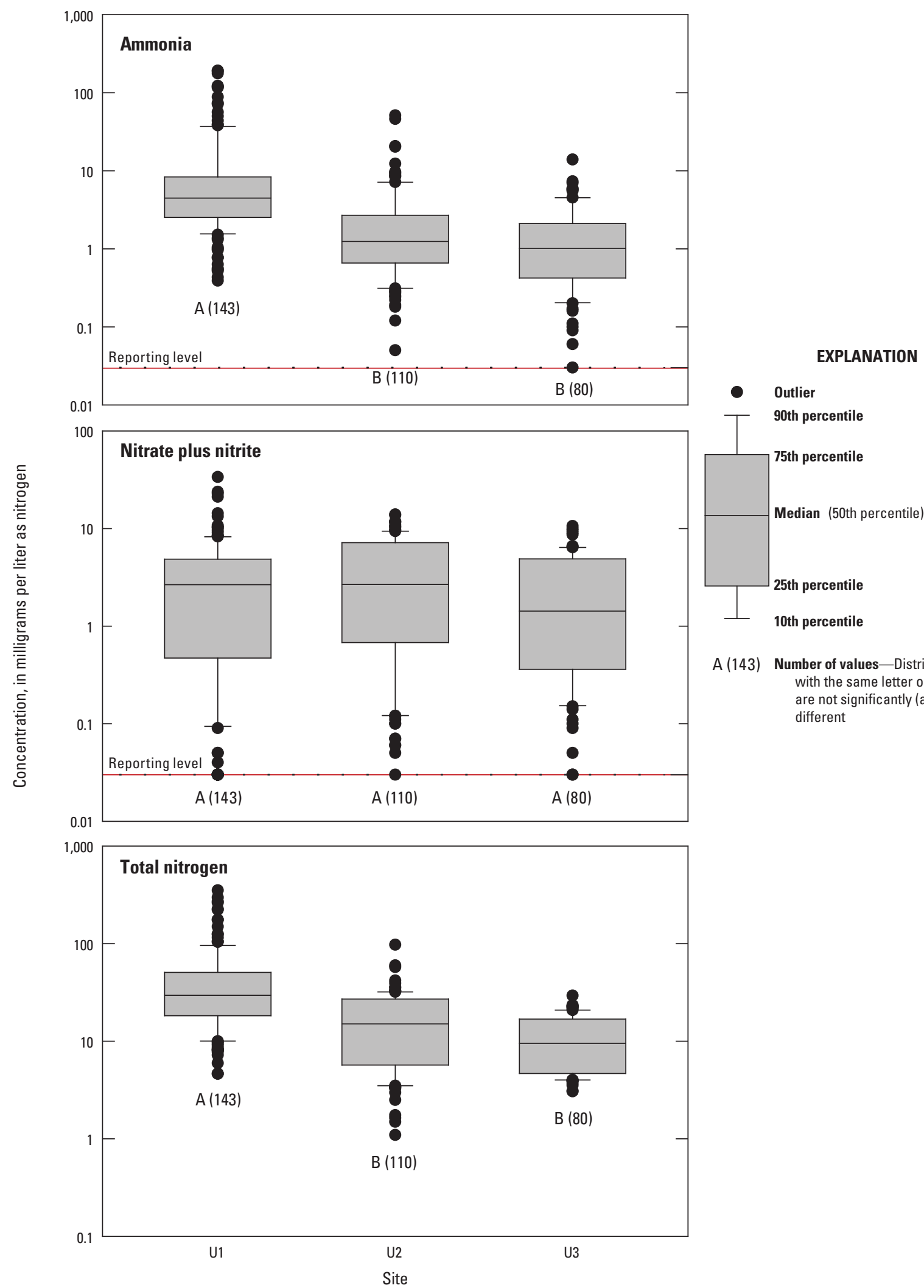

A (143) Number of values-Distributions associated with the same letter on the same graphs are not significantly (alpha less than 0.01 ) different

Figure 11. Distribution of constituent concentrations at Underwood Discovery Farms, North Dakota, 2008-2012.—Continued 

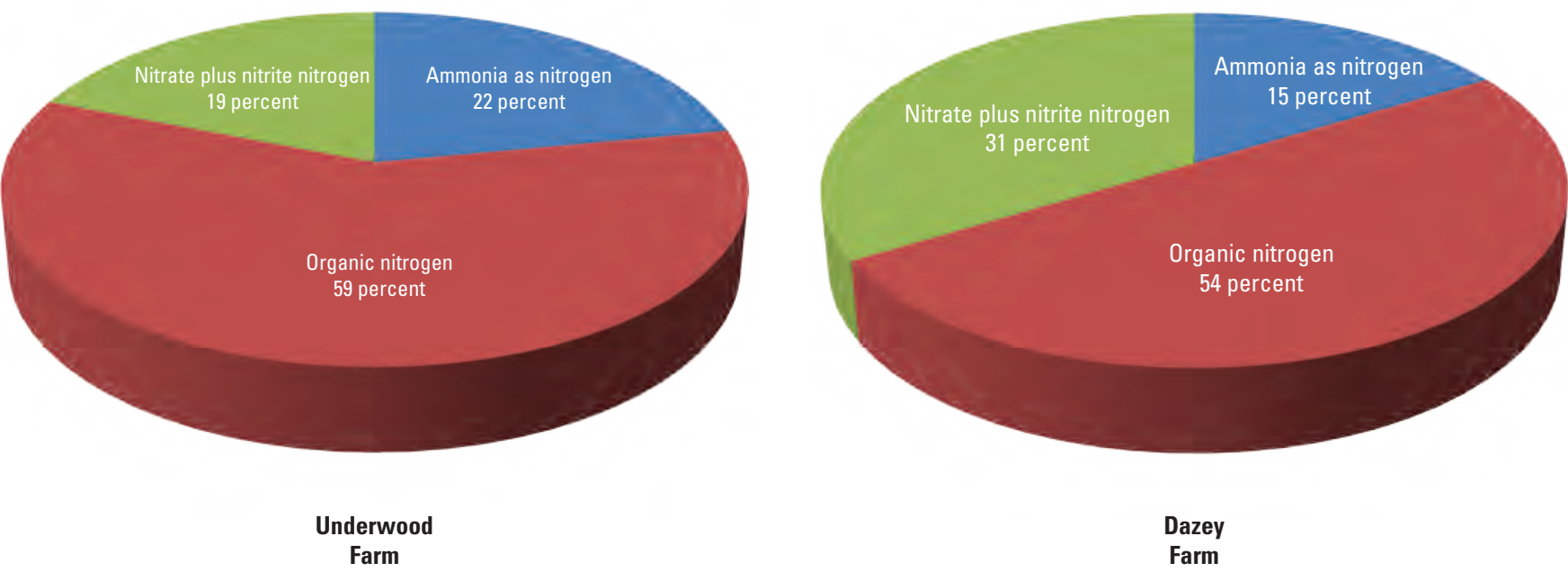

Figure 12. Speciation of nitrogen at Underwood and Dazey Farms, North Dakota, 2008-2012.

and ammonia were between 1 to 9 times greater than yields in 2010. The larger yield in 2011 relates well with annual runoff in 2011 at Underwood Farm, which, on average, was 1.5 times greater than runoff in 2010 (fig. 8). Consistent with nitrate plus nitrite annual loads, annual nitrate plus nitrite yields were largest in 2010 .

\section{Dazey Farm}

Variability in concentrations among sites at Dazey Farm (fig. 1) was predominantly affected by local topography and surface-groundwater interactions. D1 and D2 are located towards the top of a hill, in a gully with steep sides, and duration of flow during a runoff event is short. In contrast, D3 is located at the base of the hill and seems to be affected by groundwater. It is likely that groundwater contributes to surface runoff at D3 because flow continued at D3 after flow stopped at the other sites, and a trickle of flow (less than 0.001 cubic foot per second) continues throughout the summer (W. C. Damschen, U.S. Geological Survey, oral commun., 2014). The steepness of the hill and side channels at D1 and D2 caused mud flows during high flows that complicated efforts to maintain and operate the flumes resulting in fewer samples being collected at D1 and D2 (table 4). Data for D2 are presented, but because there are few samples and some of the samples were affected by mud flows, general comparisons were made between D1 (closest site to the feeding area) and D3 (farthest site from the feeding area). The median chloride concentration was significantly higher at D3 than D1 (fig. 15) ranging from $3.53 \mathrm{mg} / \mathrm{L}$ at D1 to $73.2 \mathrm{mg} / \mathrm{L}$ at D3. Higher concentrations of chloride at D3 is likely from saline groundwater contribution, but also could be caused by weathering of surficial materials and soils (Mullaney and others, 2009). Suspended sediment, total phosphorus, and ammonia concentrations were significantly lower at D3 than at D1 (fig. 15) likely because of dilution from surrounding crop land, and the location of D3 at the base of the hill allows sediment and associated particulate phosphorus to settle out. Nitrate plus nitrite and total nitrogen median concentrations were not significantly different between D1 and D3 likely because of surface-groundwater interaction, nitrification, and denitrification. Similar to Underwood Farm, the predominant form of nitrogen at Dazey Farm was organic nitrogen (fig. 12).

For suspended sediment, total phosphorus, and ammonia, annual loads and yields at D3 were larger in 2010 than 2011 (figs. 13 and 14), which was consistent with the pattern in precipitation and runoff (figs. 6 and 8). The sediment load was three times larger in 2010 than in 2011, but runoff only was 1.5 times greater in 2010 than 2011. The much larger sediment load in 2010 was the result of a single runoff event on May 24, 2010. On May 24, the daily mean concentration for suspended sediment was $10,300 \mathrm{mg} / \mathrm{L}$. For chloride and nitrate plus nitrite, the largest annual loads did not coincide with the year of largest runoff, which may be caused by groundwater interaction with the surface runoff. Annual loads and yields for chloride were nearly the same in 2010 and 2011 (figs. 13 and 14). For nitrate plus nitrite, annual loads and yields were larger in 2011 than 2010 (figs. 13 and 14).

\section{Embden Farm}

Among sites at Embden Farm (fig. 1), water-quality patterns emerged, which reflected differences between surface drainage and subsurface drainage systems. The following differences between surface and subsurface drainage systems at Embden Farm were similar to those documented by Neely and Baker (1989): (1) ammonia concentrations were similar between surface drainage and subsurface drainage, (2) 


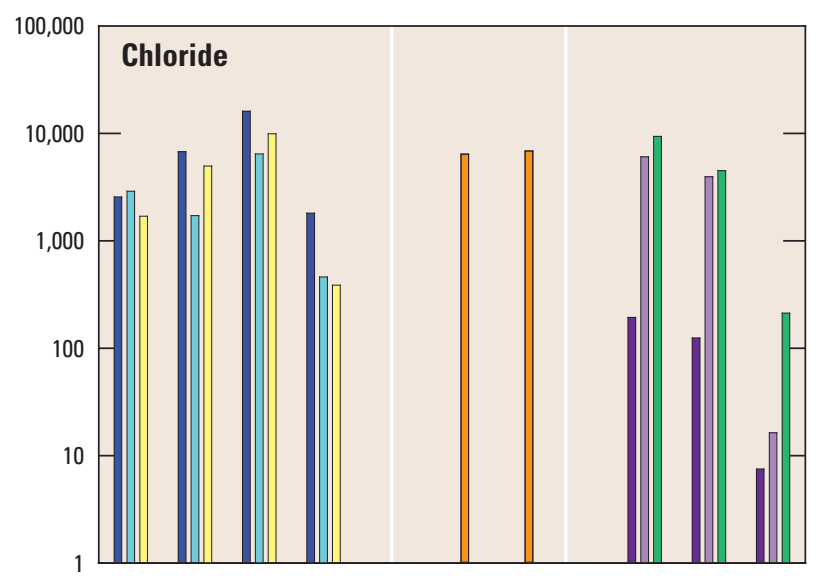

EXPLANATION
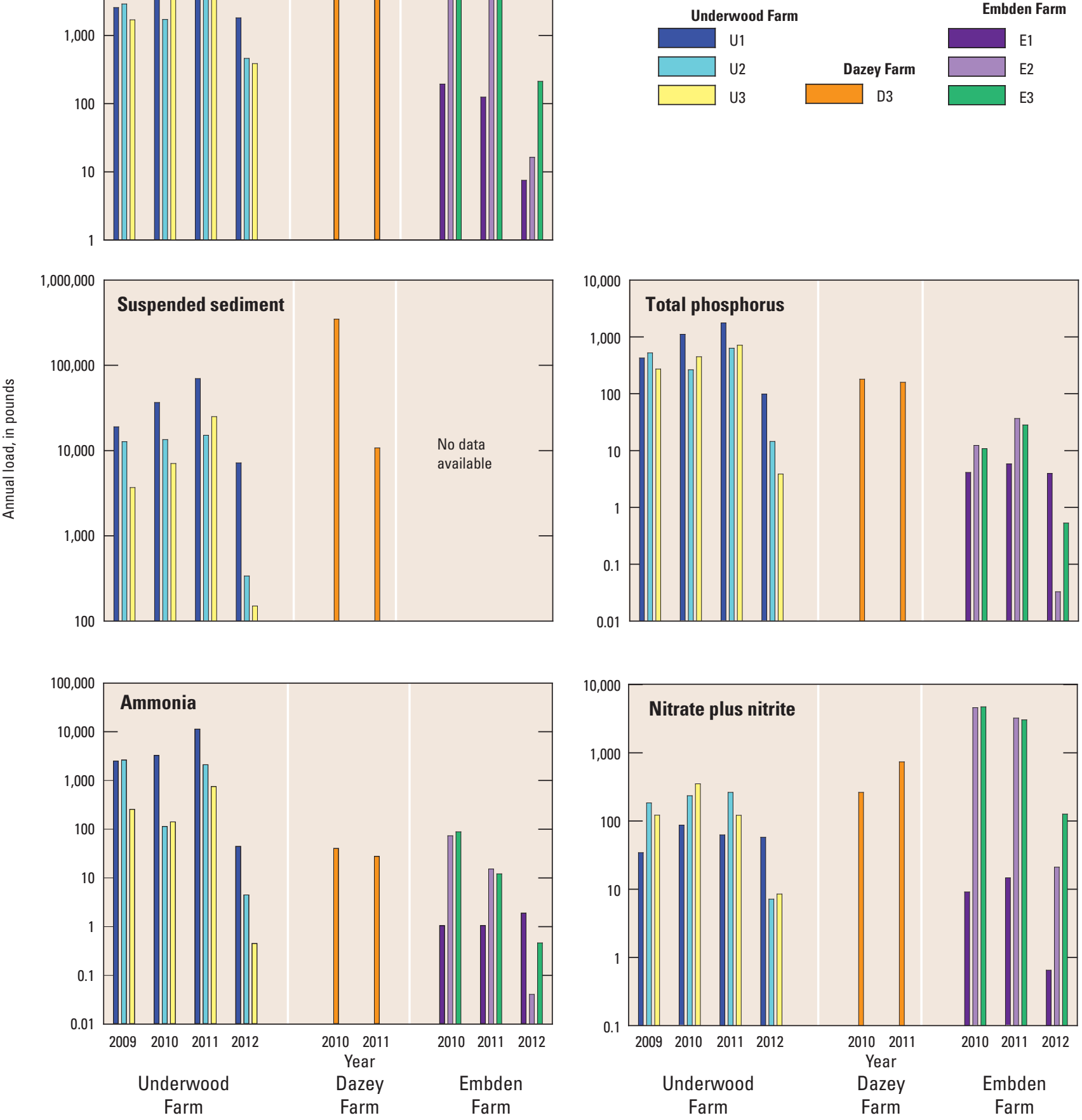

Figure 13. Annual loads for Discovery Farms in North Dakota, 2009-2012. 


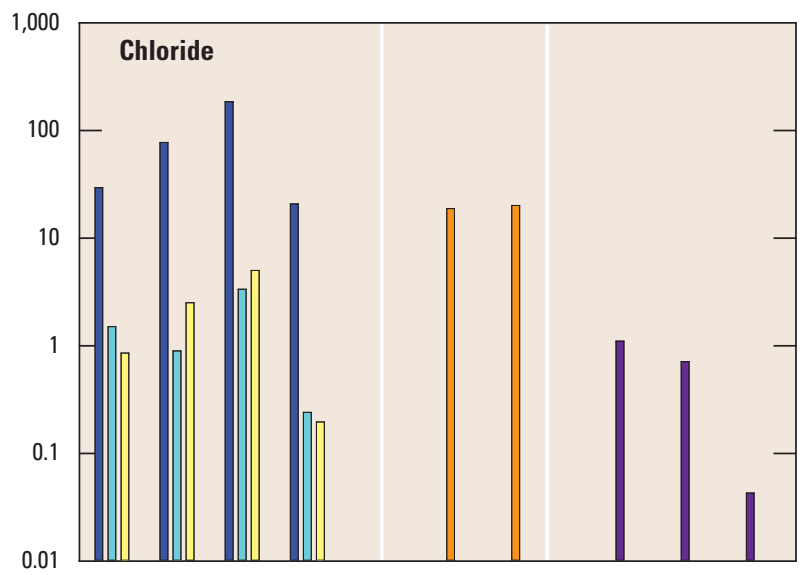

EXPLANATION
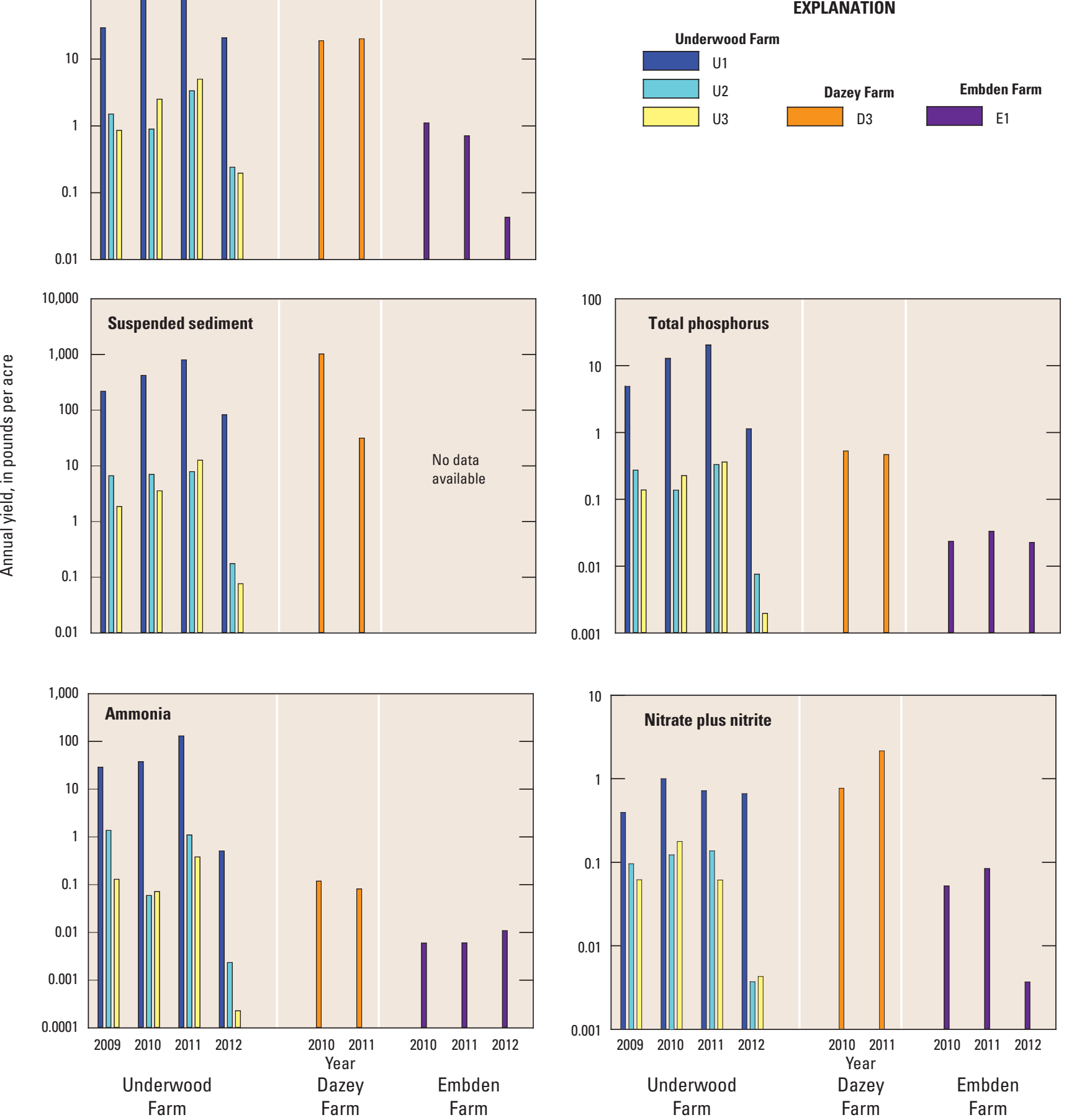

Figure 14. Annual yields for Discovery Farms in North Dakota, 2009-2012. 


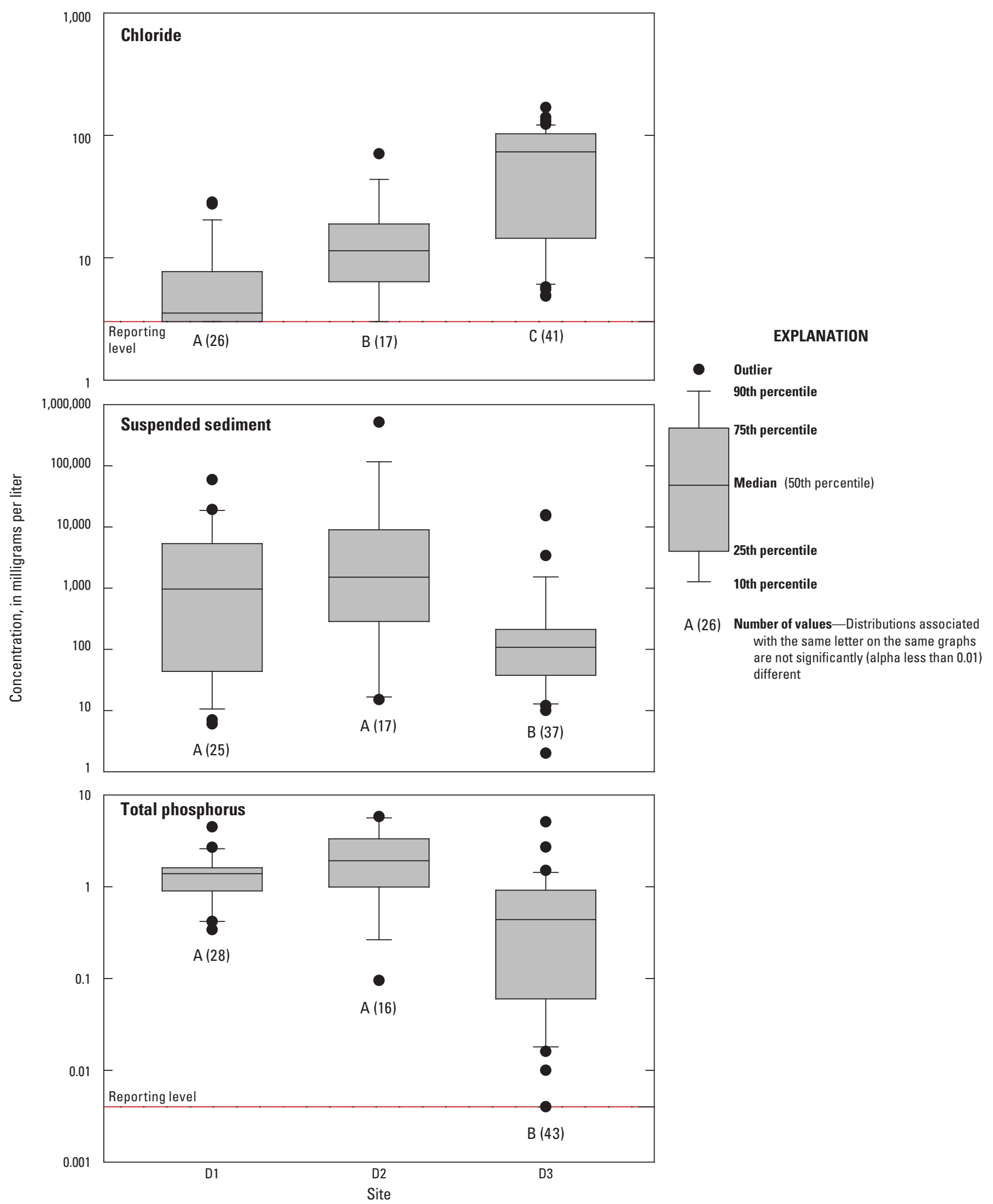

Figure 15. Distribution of constituent concentrations at Dazey Farm, North Dakota, 2009-2012. 


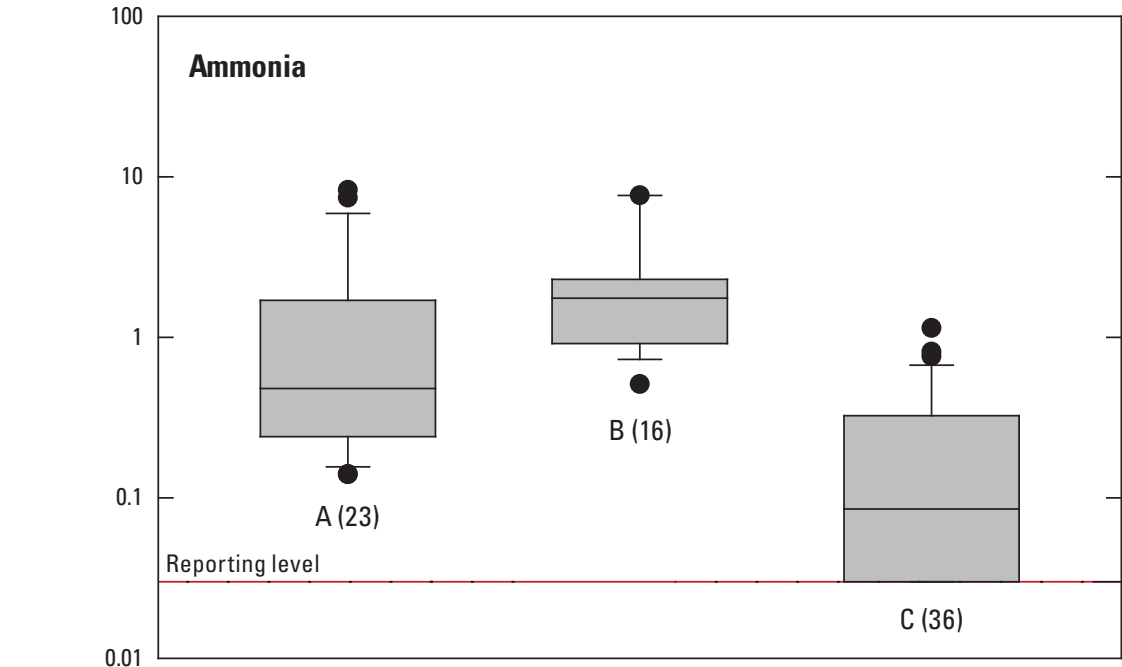

\section{EXPLANATION}

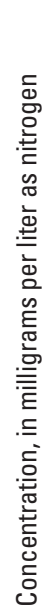
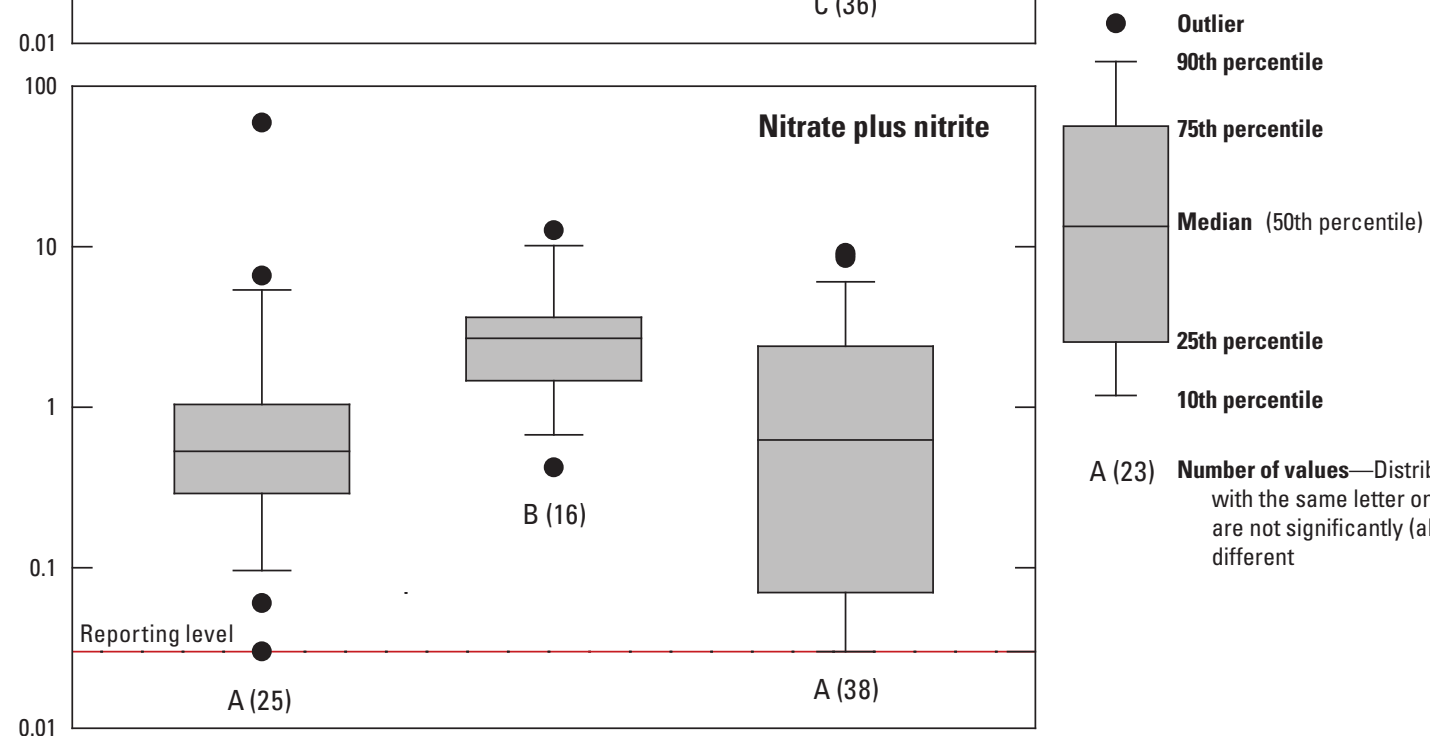

A (23) Number of values-Distributions associated with the same letter on the same graphs are not significantly (alpha less than 0.01 ) different

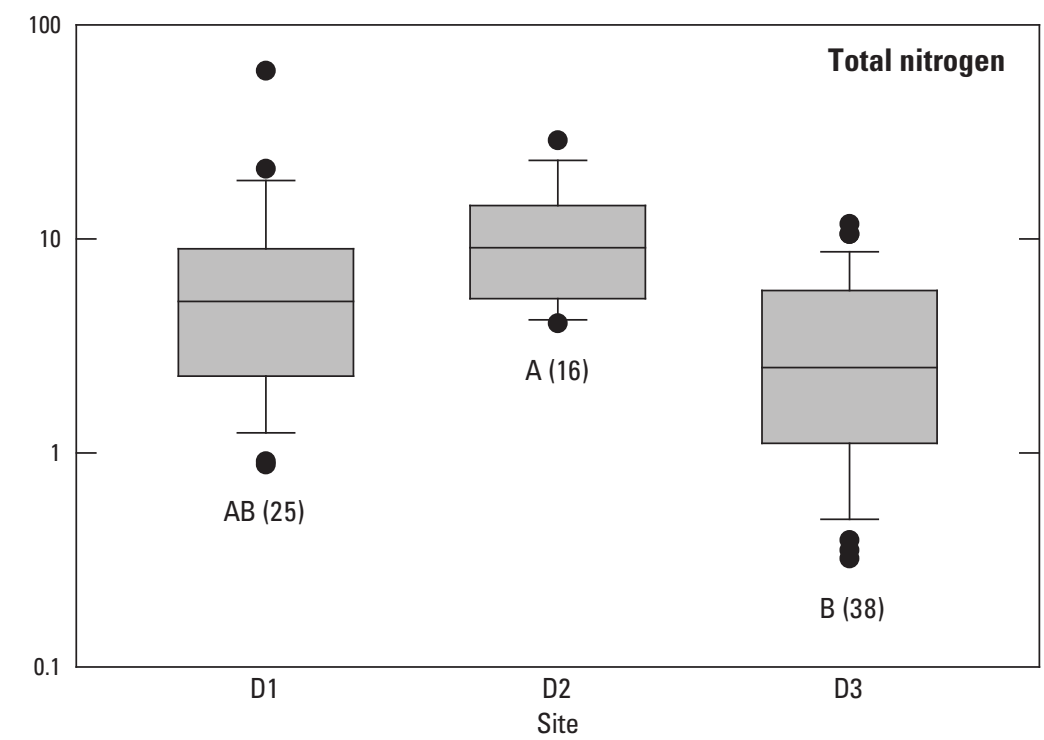

Figure 15. Distribution of constituent concentrations at Dazey Farm, North Dakota, 2009-2012._Continued 
phosphorus concentrations generally were higher in surface drainage, and (3) nitrate nitrogen concentrations in subsurface drainage were 10 to 100 times higher than surface drainage. For Embden Farm, ammonia concentrations ranged from less than 0.03 to $1.95 \mathrm{mg} / \mathrm{L}$ with no statistically significant difference among sites (fig. 16). Total phosphorus concentrations were significantly higher at surface drainage site E1 with a median concentration of $0.19 \mathrm{mg} / \mathrm{L}$ compared with a median concentration of $0.021 \mathrm{mg} / \mathrm{L}$ at E2 (fig. 16). Nitrate plus nitrite concentrations and total nitrogen concentrations were 10 to 100 times higher at E2 and E3 compared to E1, and differences were statistically significant. The maximum nitrate plus nitrite concentration at E1 of $0.89 \mathrm{mg} / \mathrm{L}$ is less than the minimum concentration of $0.95 \mathrm{mg} / \mathrm{L}$ at E2. Similar to nitrate plus nitrite, chloride concentrations at E2 and E3 were significantly higher than at E1 and ranged from less than $3.00 \mathrm{mg} / \mathrm{L}$ at E1 to $41.4 \mathrm{mg} / \mathrm{L}$ at E3 (fig. 16). High solubility allows nitrate plus nitrite to readily flow through the soil and into tile lines (U.S. Environmental Protection Agency, 2013), but groundwater also may be contributing to higher nitrate plus nitrite and chloride concentrations at the subsurface drainage sites.

The speciation of nitrogen between the surface drainage site and subsurface drainage sites was distinctly different (fig. 17). The predominant form of nitrogen at $\mathrm{E} 1$ was organic nitrogen (68 percent), which is consistent with surface drainage sites at Underwood and Dazey Farms (fig. 12). For the subsurface drainage sites, the predominant form of nitrogen was nitrate plus nitrite (93 percent), which is consistent with subsurface drainage sites at Discovery Farms in Wisconsin (University of Wisconsin-Extension Discovery Farms, 2013).

At the Embden Farm, during the wet years of 2010 and 2011, the subsurface drainage sites (E2 and E3) had the highest flow volumes and the largest annual loads (fig. 7, fig. 13). In 2010 and 2011, annual loads of chloride, ammonia, and nitrate plus nitrite at the subsurface drainage sites were 10 to 1,000 times greater than annual loads at the surface drainage site (E1). Total phosphorus concentrations were significantly lower at E2 and E3 compared with E1 (fig. 16), but because of

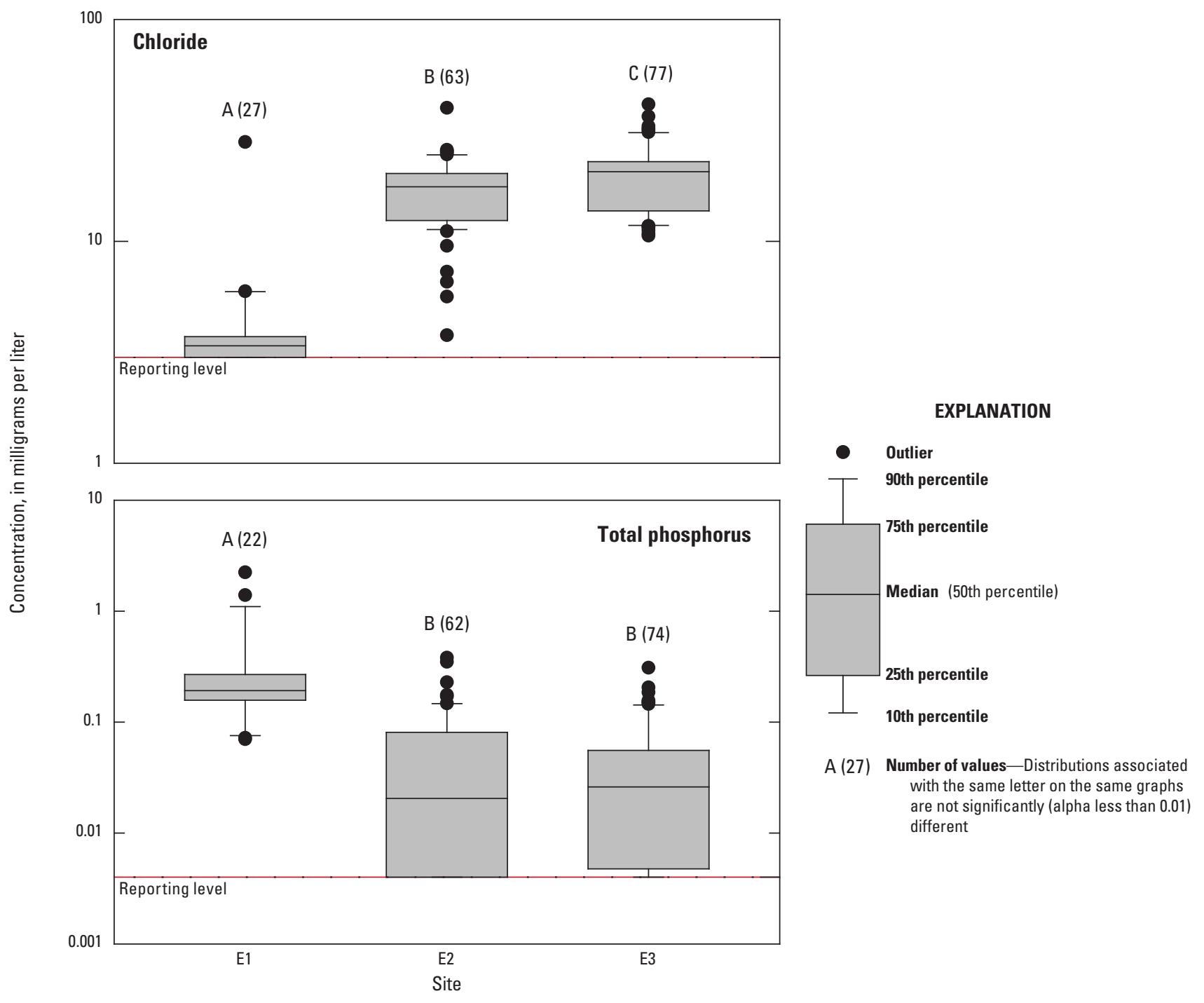

Figure 16. Distribution of constituent concentrations at Embden Farm, North Dakota, 2009-2012. 

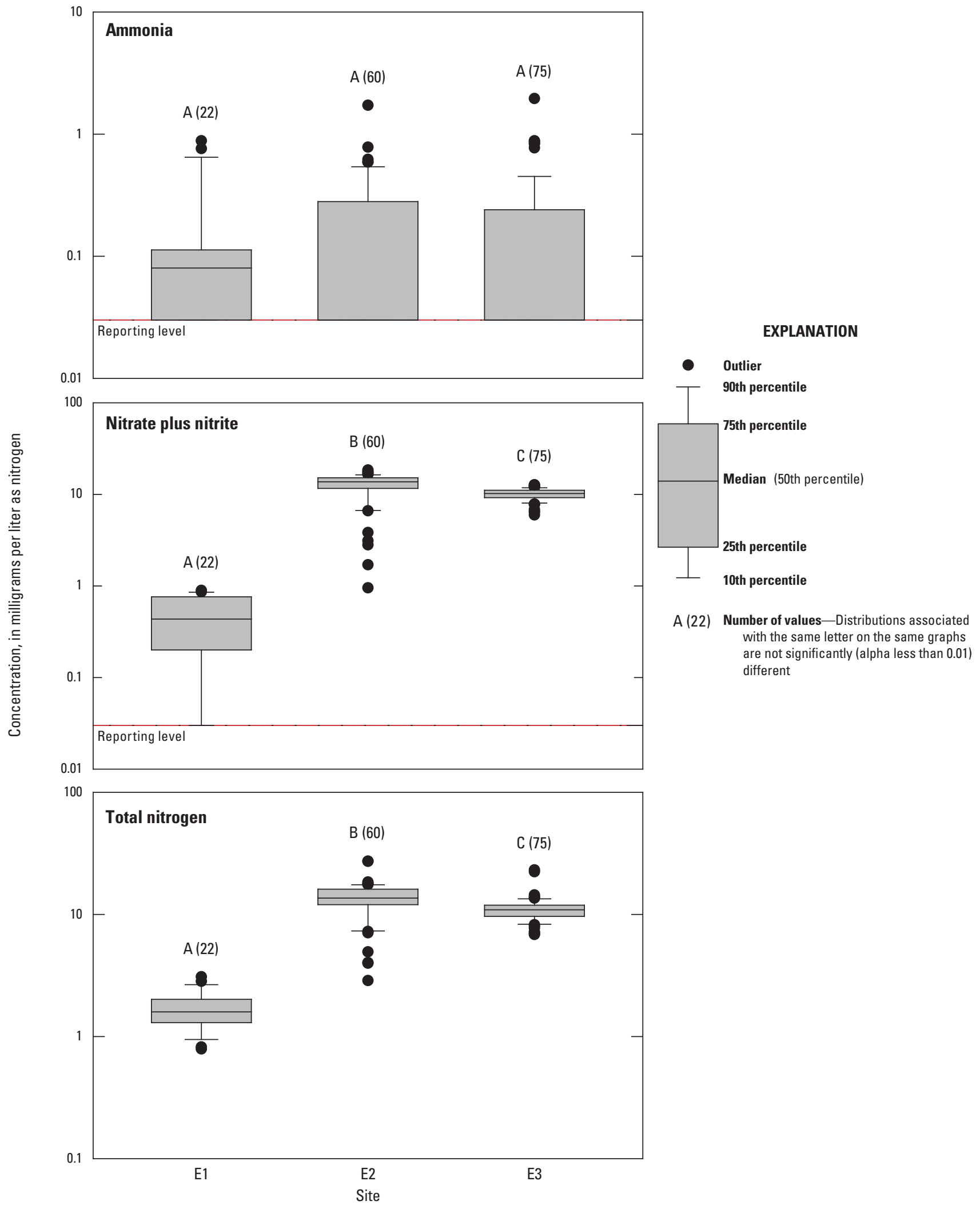

Figure 16. Distribution of constituent concentrations at Embden Farm, North Dakota, 2009-2012.-Continued 


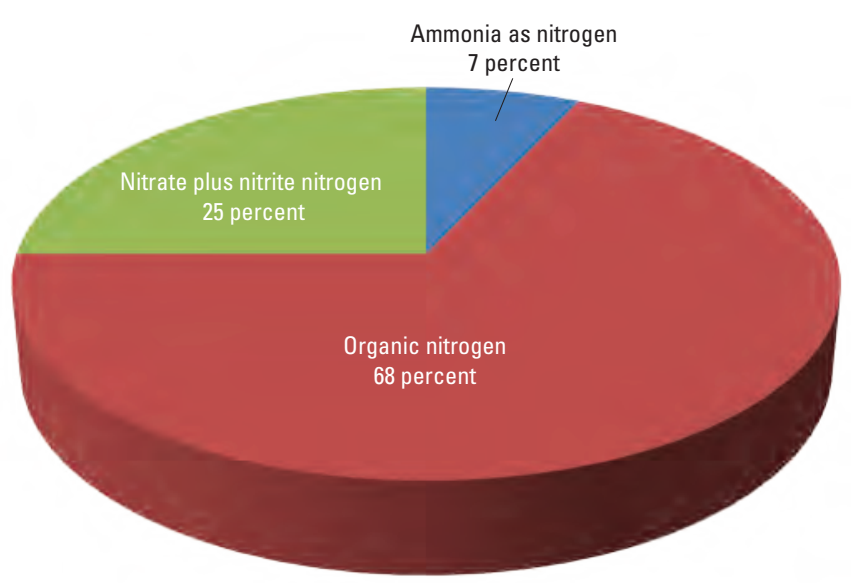

Embden 1

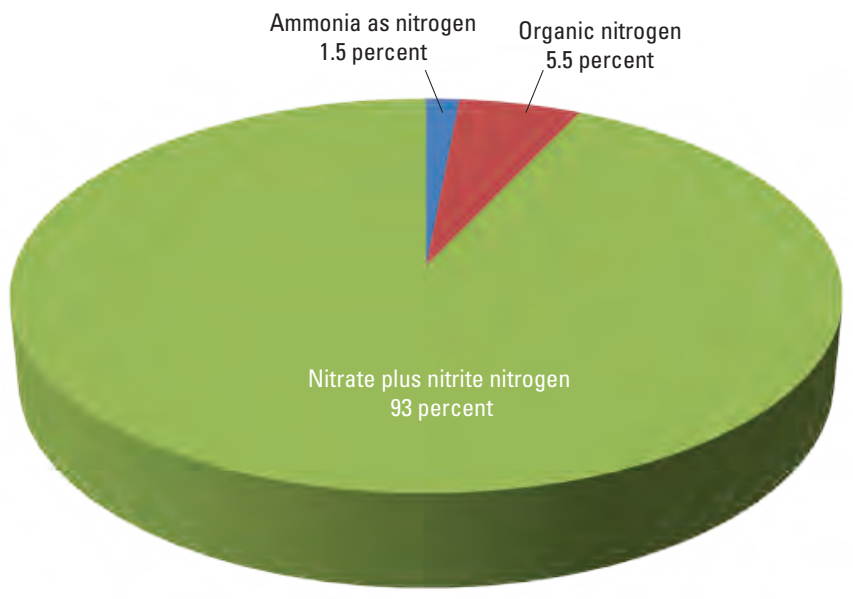

Embden 2 and 3

Figure 17. Speciation of nitrogen at Embden Farm, North Dakota, 2009-2012.

higher flow volumes, in 2010 and 2011, total phosphorus loads were larger at E2 and E3 than E1. Other than total phosphorus, loads generally were largest in 2010, which corresponded to the year of highest precipitation and flow volume. In contrast, during the dry year of 2012 (fig. 6), total phosphorus and ammonia loads were larger at the surface drainage site (E1) than at subsurface drainage sites (E2 and E3; fig. 16).

For Embden Farm, yields were computed for the surface drainage site, E1. For chloride, yields were less than $1 \mathrm{lb}$ /acre with the largest yield in 2010 (fig. 14). For total phosphorus and nitrate plus nitrite, the largest annual yield was in 2011, which is consistent with the year with the highest runoff (figs. 8 and 14). Total phosphorus and ammonia yields varied little from year to year and generally were less than $0.1 \mathrm{lb} /$ acre.

Consistent patterns in water quality emerged at each individual farm, but similarities among farms also were observed. Suspended sediment, total phosphorus, and ammonia concentrations generally decreased downstream from feeding areas, and were primarily affected by surface runoff processes such as dilution, settling out of sediment, or vegetative uptake. Because surface runoff affects these constituents, increased annual surface runoff tended to result in increased loads and yields. No significant change in nitrate plus nitrite concentrations were observed downstream from feeding areas because additional processes such as high solubility, nitrification, denitrification, and surface-groundwater interaction affect nitrate plus nitrite. For nitrate plus nitrite, increases in annual runoff did not consistently relate to increases in annual loads and yields. It appears that temporal distribution of precipitation and surface-groundwater interaction affected nitrate plus nitrite loads and yields. For surface drainage sites (U1-3, D1-3, and E1), the predominant form of nitrogen was organic nitrogen whereas for subsurface drainage sites (E2 and E3), the predominant form of nitrogen was nitrate plus nitrite nitrogen.

\section{Summary}

North Dakota has implemented several policies with the goal of minimizing runoff from animal feeding operations; however, little data have been collected to evaluate the effects of runoff from feeding operations on water quality or improvements in water quality resulting from changes in animal feeding operation practices. In response to this lack of data, the U.S. Geological Survey, in cooperation with North Dakota State University Agriculture Research Extension and in collaboration with North Dakota State Department of Health, North Dakota State Water Commission, U.S. Environmental Protection Agency, and several agricultural producers helped organize a Discovery Farms program in North Dakota in 2007. Discharge measurements and water-quality samples collected at the three Farms, Underwood, Dazey, and Embden, were used to describe water-quality characteristics in runoff, and compute estimates of annual loads and yields for selected constituents from spring 2008 through fall 2012.

At Underwood Farm, concentrations generally decreased from upstream to downstream because of proximity to the feedlot and grassy depressions located between sites. With the exception of nitrate plus nitrite, a statistically significant decrease in concentration from upstream to downstream generally was observed. At downstream sites, less concentrated runoff from surrounding crop land likely caused some dilution. In the grassy depressions between sites, particulate phosphorus likely was removed from sediment settling out, and dissolved phosphorus likely was removed by vegetation. For nitrate plus nitrite, the surface runoff processes that dominated other constituents (dilution, settling out, vegetative uptake) were moderated by other processes specific to nitrate plus nitrite (high solubility, nitrification, and denitrification) resulting in no significant change in concentrations from upstream to downstream. For constituents other than nitrate plus nitrite, dilution, 
settling out of sediment particles, and vegetative uptake likely contributed to the decrease in constituent concentration from upstream to downstream. The predominant form of nitrogen at Underwood Farm was organic nitrogen (59 percent of total nitrogen), which is consistent with surface drainage sites at Discovery Farms in Wisconsin.

At Underwood Farm, consistent with constituent concentrations of chloride, suspended sediment, total phosphorus, and ammonia, the largest loads typically were observed at the upstream site, and the smallest loads were observed at the downstream site. Consistent with annual flow volumes, for constituents other than nitrate plus nitrite, the smallest annual loads were in 2012, and the largest annual loads were in 2011. Although the largest nitrate plus nitrite loads generally were observed in 2010, 2011 was the year with the largest amount of flow volume. The temporal distribution of precipitation may have contributed to the larger nitrate plus nitrite loads in 2010.

Similar to loads, with the exception of nitrate plus nitrite, the largest annual yields at Underwood Farm were in 2011 at the most upstream site, and the smallest annual yields were in 2012 at the most downstream site. The larger yield in 2011 relates well with annual runoff in 2011 at Underwood Farm, which, on average, was 1.5 times greater than runoff in 2010. Consistent with nitrate plus nitrite annual loads, annual nitrate plus nitrite yields were largest in 2010.

Variability in concentrations among sites at Dazey Farm was predominantly affected by local topography and surfacegroundwater interactions. Chloride concentrations were highest at the site farthest downstream likely because of groundwater contribution. Suspended sediment, total phosphorus, and ammonia concentrations were significantly lower at the downstream site likely because of dilution and settling out of sediment. Nitrate plus nitrite concentrations were not significantly different from upstream to downstream likely because surface-groundwater interaction, nitrification, and denitrification. Similar to Underwood Farm, the predominant form of nitrogen at Dazey Farm was organic nitrogen.

For suspended sediment, total phosphorus, and ammonia, annual loads and yields at Dazey Farm were larger in 2010 than 2011, which was consistent with the pattern in precipitation and runoff. The sediment load was three times greater in 2010 than in 2011, but runoff only was 1.5 times larger in 2010 than 2011. The much larger sediment load in 2010 was the result of a single runoff event on May 24, 2010. On May 24 , the daily mean concentration for suspended sediment was $10,300 \mathrm{mg} / \mathrm{L}$. For chloride and nitrate plus nitrite, the largest annual loads did not coincide with the year of largest runoff, which may be caused by groundwater interaction with the surface runoff.

Among sites at Embden Farm, water-quality patterns emerged, which reflected differences between surface drainage and subsurface drainage systems, and similar differences have been documented in other reports. Unlike other constituents, there were no statistically significant differences in ammonia concentrations among sites. Total phosphorus concentrations were significantly higher at the surface drainage site. Nitrate plus nitrite concentrations and total nitrogen concentrations were 10 to 100 times higher at subsurface drainage sites compared to the surface drainage site, and differences were statistically significant. Similar to nitrate plus nitrite, chloride concentrations were significantly higher at subsurface drainage sites than the surface drainage site. High solubility allows nitrate plus nitrite to readily flow through the soil and into tile lines, but groundwater also may be a contributing to higher nitrate plus nitrite and chloride concentrations at the subsurface drainage sites. The speciation of nitrogen between the surface drainage site and subsurface drainage sites was distinctly different. The predominant form of nitrogen at the surface drainage site was organic nitrogen (68 percent), which is consistent with surface drainage sites at Underwood and Dazey Farms. For the subsurface drainage sites, the predominant form of nitrogen was nitrate plus nitrite (93 percent), which is consistent with subsurface drainage sites at Discovery Farms in Wisconsin.

At the Embden Farm, during the wet years of 2010 and 2011, the subsurface drainage sites had the highest flow volumes and the largest annual loads. In 2010 and 2011, annual loads of chloride, ammonia, and nitrate plus nitrite at the subsurface drainage sites were 10 to 1,000 times greater than annual loads at the surface drainage site. Other than total phosphorus, loads generally were largest in 2010 , which corresponded to the year of highest precipitation and flow volume.

Consistent patterns in water quality emerged at each individual farm, but similarities among farms also were observed. Suspended sediment, total phosphorus, and ammonia concentrations generally decreased downstream from feeding areas and were primarily affected by surface runoff processes such as dilution, settling out of sediment, or vegetative uptake. Because surface runoff affects these constituents, increased annual surface runoff tended to result in increased loads and yields. No significant change in nitrate plus nitrite concentration were observed downstream from feeding areas because additional processes such as high solubility, nitrification, denitrification, and surface-groundwater interaction affect nitrate plus nitrite. For nitrate plus nitrite, increases in annual runoff did not consistently relate to increases in annual loads and yields. It appears that temporal distribution of precipitation and surface-groundwater interaction affected nitrate plus nitrite loads and yields. For surface drainage sites, the primary form of nitrogen was organic nitrogen, whereas the primary form of nitrogen was nitrate plus nitrite nitrogen for subsurface drainage sites. 


\section{References Cited}

Bluemle, J., and Biek, B., 2007, No ordinary plain—North Dakota's physiography and landforms: North Dakota Geological Survey, North Dakota Notes No. 1, accessed July 2011 at https://www.dmr.nd.gov/ndgs/ndnotes/ndn1.htm.

Clesceri, L.S., Greenberg, A.E., and Eaton, A.D., eds., 1999, Standard methods for the examination of water and wastewater (20th ed.): American Public Health Association, $1,325 \mathrm{p}$.

Community Collaborative Rain, Hail and Snow Network, 2013, CoCoRaHS Water Year Summary Reports: accessed April 8, 2013, at http://www.cocorahs.org/WaterYearSummary/.

Drummy, N., Cooley, E., Wunderlin, A., Radatz, A., Frame, D., and Klingberg, K., 2011, Understanding nutrient and sediment loss at Koepke Farms, Inc.: accessed January 27, 2014, at http://www.uwdiscoveryfarms.org/.

Guy, H.P., 1969, Laboratory theory and methods for sediment analysis: U.S. Geological Survey Techniques of WaterResources Investigations Report, book 5, chap. C1, 58 p.

Helsel, D.R., and Hirsch, R.M., 2002, Statistical methods in water resources: U.S. Geological Survey Techniques of Water-Resources Investigations, book 4, chap. A3, 510 p.

Helsel, D.R., 2005, Nondetects and data analysis: John Wiley \& Sons, Hoboken, New Jersey, 250 p.

Jensen, R.E., [n.d.], Climate of North Dakota: Jamestown, N. Dak., National Weather Service, North Dakota State University, Northern Prairie Wildlife Research Center Online, http://www.npwrc.usgs.gov/resource/habitat/climate/index. htm.

Minnesota Pollution Control Agency, 2007, PhosphorusSources, forms, impact on water quality: accessed December 12, 2013, at http://www.pca.state.mn.us/index.php/viewdocument.html?gid=8547.

Mullaney, J.R., Lorenz, D.L., and Arntson, A.D., 2009, Chloride in groundwater and surface water in areas underlain by the glacial aquifer system, northern United States: U.S. Geological Survey Scientific Investigations Report 20095086, $41 \mathrm{p}$.

Neely, R.K., and Baker, J.L., 1989, Northern prairie wetlands: Ames, Iowa, University Press, p. 92-131.

North Dakota Department of Health, 2012, North Dakota 2012 Integrated Section 305(b) water quality assessment report and section 303(d) list of waters needing total maximum daily loads: accessed September 26, 2014, at http://www. ndhealth.gov/WQ/SW/Z7_Publications/IntegratedReports/ Final_2012_IntegratedReport_20121029.pdf
North Dakota Department of Health, 2014, Animal feeding operations program: accessed January 7, 2013, at http:// www.ndhealth.gov/wq/animalfeedingoperations/afoprogram.htm.

North Dakota Agricultural Weather Network, 2013, NWS monthly normals data table: accessed April 4, 2013, at http://ndawn.ndsu.nodak.edu/nws-monthly-normals-tableform.html.

North Dakota State Climate Office, 2013a, 30 year average-1981-2010 normals: accessed April 4, 2013, at http:// www.ndsu.edu/ndsco/normals/8110normals/NDnorm.pdf.

North Dakota State Climate Office, 2013b, North Dakota monthly precipitation: accessed April 8, 2013, at http:// www.ndsu.edu/ndsco/precip/monthly/2013.html.

North Dakota State University, 2009, Enabling grass-roots, intensive, runoff water monitoring projects: the North Dakota Discovery Farms: accessed December 5, 2014, at http://www.ag.ndsu.edu/df/documents/7-09DiscoveryFarmsNCER.pdf

Randall, G.W., and Mulla, D.J., 2001, Nitrate nitrogen in surface waters as influenced by climatic conditions and agricultural practices: Journal of Environmental Quality, v. 30, p. 337-344.

Rus, D.L., Patton, C.J., Mueller, D.K., and Crawford, C.G., 2013, Assessing total nitrogen in surface-water samplesPrecision and bias of analytical and computational methods: U.S. Geological Survey Scientific Investigations Report 2012-5281, 38 p.

Sauer, V.B., and Turnipseed, D.P., 2010, Stage measurement at gaging stations: U.S. Geological Survey Techniques and Methods, book 3, chap. A7, 45 p. [Also available at http:// pubs.usgs.gov/tm/tm3-a $7 /$.

Stuntebeck, T.D., Komiskey, M.J., Owens, D.W., and Hall, D.W., 2008, Methods of data collection, sample processing, and data analysis for edge-of-field, streamgaging, subsurface-tile, and meteorological stations at Discovery Farms and Pioneer Farm in Wisconsin, 2001-7: U.S. Geological Survey Open-File Report 2008-1015, 51 p.

Stuntebeck, T.D., Komiskey, M.J., Peppler, M.C., Owens, D.W., and Frame, D.R., 2011, Precipitation-runoff relations and water-quality characteristics at edge-of-field stations, Discovery Farms and Pioneer Farm in Wisconsin, 2003-8: U.S. Geological Survey Scientific Investigations Report 2011-5008, 46 p.

Tracom, 2014a, Discharge for 2.0' H flume: accessed December 29, 2014, at http://tracomfrp.com/flumes/discharge_ tables/h_flume/20h_discharge_table.pdf. 


\section{References Cited}

Tracom, 2014b, Discharge for 2.5' H flume: accessed December 29, 2014, at http://tracomfrp.com/flumes/discharge tables/h_flume/25h_discharge_table.pdf.

Tracom, 2014c, Trapedoizal flumes sizes and recommended flow ranges for extra large 60 degree V: accessed December 29, 2014, at http://tracomfrp.com/wastewater_applications/ flumes/trapezoidal-flumes/.

University of Wisconsin-Extension Discovery Farms, 2013, Understanding nutrient and sediment loss at Koepke Farms, Inc.: accessed August 8, 2013, at http://uwdiscoveryfarms. org/.

U.S. Environmental Protection Agency, 2013a, Approved general-purpose methods: accessed November 12, 2013, at http://water.epa.gov/scitech/methods/cwa/methods_index. $\mathrm{cfm}$.

U.S. Environmental Protection Agency, 2013b, Ag 101: accessed August 7, 2013, at http://www.epa.gov/oecaagct/ ag101/impactnitrate.html.
U.S. Environmental Protection Agency, 2013c, Ag 101: accessed August 8, 2014, at http://www.epa.gov/agriculture/ ag101/cropdrainage.html.

U.S. Geological Survey, 2013, National Water Information System (NWIS): U.S. Geological Survey database, accessed April 12, 2013, at http://nwis.waterdata.usgs.gov/nd/nwis.

U.S. Geological Survey, 2014, StreamStats: accessed December 30, 2014, at http://water.usgs.gov/osw/streamstats/ ssonline.html. [North Dakota StreamStats implementation is currently (2014) underway with full implementation expected in the future.]

U.S. Geological Survey, variously dated, National field manual for the collection of water-quality data: U.S. Geological Survey Techniques of Water-Resources Investigations, book 9, chaps. A1-A9, available online at http://pubs.water.usgs. gov/twri9A. 
Publishing support provided by: Rolla Publishing Service Center

For more information concerning this publication, contact: Director, USGS North Dakota Water Science Center 821 East Interstate Avenue Bismarck, North Dakota 58503

(701) 250-7400

Or visit the North Dakota Water Science Center Web site at: http://nd.water.usgs.gov/ 

